\title{
Approaches to Enhancing Gas Sensing Properties:
} A Review

\author{
Zhenyu Yuan $\mathbb{D}^{\mathbb{D}}$, Rui Li, Fanli Meng * ${ }^{\mathbb{D}}$, Junjie Zhang, Kaiyuan Zuo and Erchou Han \\ College of Information Science and Engineering, Northeastern University, Shenyang 110819, China; \\ yuanzhenyu@ise.neu.edu.cn (Z.Y.); 1800726@stu.neu.edu.cn (R.L.); 1700866@stu.neu.edu.cn (J.Z.); \\ 1800730@stu.neu.edu.cn (K.Z.); 1700723@stu.neu.edu.cn (E.H.) \\ * Correspondence: mengfanli@ise.neu.edu.cn
}

Received: 19 February 2019; Accepted: 22 March 2019; Published: 27 March 2019

\begin{abstract}
A gas nanosensor is an instrument that converts the information of an unknown gas (species, concentration, etc.) into other signals (for example, an electrical signal) according to certain principles, combining detection principles, material science, and processing technology. As an effective application for detecting a large number of dangerous gases, gas nanosensors have attracted extensive interest. However, their development and application are restricted because of issues such as a low response, poor selectivity, and high operation temperature, etc. To tackle these issues, various measures have been studied and will be introduced in this review, mainly including controlling the nanostructure, doping with 2D nanomaterials, decorating with noble metal nanoparticles, and forming the heterojunction. In every section, recent advances and typical research, as well mechanisms, will also be demonstrated.
\end{abstract}

Keywords: gas nanosensors; nanomaterials; sensing properties; mechanism

\section{Introduction}

In our life, we have contact with various harmful and flammable gases, some of which cause air pollution and affect our physical health. Based on the requirement for detecting these gases effectively, gas sensors have attracted much research interest due to their advantages, including their low cost, compact structure, long lifespan, and simple circuit [1-3]. Furthermore, the metal oxide semiconductor (MOS) gas sensor, one resistive type sensor, has become a hotspot in the field of gas sensors.

To estimate the performances of gas sensors, some parameters have been proposed, mainly including response, operation temperature, detection limit, response/recovery time, and selectivity [4,5]. Response cannot be measured directly, but can be calculated by two parameters- $R_{a}$ and $R_{g}$, where $R_{a}$ is the resistance while exposed to air and $R_{g}$ is the resistance while exposed to aimed gas. Because the change trend of resistance is related to the type of semiconductor and aimed gas, the method of calculation is distinct. The conductivity of the n-type semiconductor increases when in contact with reducing gas; yet the conductivity of the p-type semiconductor increases in an oxidizing atmosphere. Therefore, for the n-type semiconductor, the response is $R_{g} / R_{a}$ in oxidizing gas and $R_{a} / R_{g}$ in reducing gas; for the p-type semiconductor, the condition is the opposite (as shown in Table 1). Obviously, response illustrates the changing extent of sensitive materials and further denotes the sensitivity of sensors to a certain gas. Selectivity demonstrates if the specific recognition of one certain gas can be achieved by gas sensors. The operation temperature is the temperature at which sensors obtain an optimal response and generally, the response will increase first and decrease next with the increasing of the temperature. Apart from these parameters, other indices are also defined to indicate the gas sensing properties of sensors. The detection limit refers to the lowest concentration of aimed gas that sensors can respond to, which determines the application field of gas sensors. Response 
time is the period from when aimed gas is injected to when the resistance reaches a stable value in aimed gas; so, recovery time is the period from when aimed gas is removed to when the resistance reaches a stable value in air. These parameters determine the application of gas sensors.

Table 1. Response of gas sensors in different conditions.

\begin{tabular}{ccc}
\hline Type of Sensitive Material & Type of Aimed Gas & Response(S) \\
\hline \multirow{2}{*}{ n-type } & oxidizing & $R_{g} / R_{a}$ \\
& reducing & $R_{a} / R_{g}$ \\
p-type & oxidizing & $R_{a} / R_{g}$ \\
& reducing & $R_{g} / R_{a}$ \\
\hline
\end{tabular}

To a great degree, these indices are related to sensitive materials that play a vital role in gas sensors and even can be seen as their core. Therefore, to tackle the disadvantages of gas sensors, such as their low response, poor selectivity, high operation temperature, and long response/recovery time, approaches to more sensitive material have been studied widely over a long period in the past. With more research about material, it has been found that nanomaterial (at least one dimension is in the nanoscale, i.e., the range of $1 \sim 100 \mathrm{~nm}$ ) is a more suitable candidate than traditional material for gas sensing because its unique properties (such as its optical property, electrical property, thermal property, magnetic property, mechanical property, etc.) resulted from specific effects, for example, the quantum confinement effect, surface effect, macroscopic quantum tunneling effect, and small size effect [6]. For gas sensing properties, nanostructure and morphology, denoting the combination and arrangement of basic units (electrons, ions, atoms, or molecules, etc.) that make up nanomaterials, are effective. As more investigations have continued, it has been found that a regular and ordered nanostructure and morphology, decorating or doping with other materials, and forming a heterojunction could exert additional influences on materials and further improve their gas sensing properties, which will be introduced in the following sections.

\section{Controlling the Type and Morphology of Nanostructures}

\subsection{The Type and Morphology of Nanostructures}

\subsubsection{The Type of Nanostructures}

Generally, according to the number of dimensions in the nanoscale, nanostructures can be classified as one of three kinds: zero-dimensional structure (0D structure), one-dimensional structure (1D structure), and two-dimensional structure (2D structure). Besides, composite structures constructed by one or more low dimensional structures are also known as a three-dimensional structure (3D structure). The classification of nanostructures and corresponding typical morphology are shown in Table 2.

Table 2. The classification of nanostructures and typical morphology.

\begin{tabular}{|c|c|c|}
\hline & The Character of Structure & Typical Morphology \\
\hline OD structure & three dimensions are in the nanoscale & Nanoparticle [7], quantum dot [8], nanocluster [9] \\
\hline 1D structure & two dimensions are in the nanoscale & $\begin{array}{l}\text { Nanowire [10], nanofiber [11], nanorod [12], } \\
\text { nanotube }[13,14]\end{array}$ \\
\hline 2D structure & one dimension is in the nanoscale & Nanosheet [15], nanobelt [16], superlattice [17] \\
\hline 3D structure & $\begin{array}{l}\text { assembled by one kind or more low } \\
\text { dimensional materials }\end{array}$ & Nanoflowers [18] \\
\hline
\end{tabular}

The type of nanostructure has a significant influence on the properties of nanomaterials. In other words, the same nanomaterials with different nanostructures may exhibit distinct properties and be suitable for different applications. For example, Ma et al. [19] fabricated $\mathrm{ZnO}$ nanorods by 
the hydrothermal method without any catalyst and obtained $\mathrm{ZnO}$ nanoflowers composed of their as-prepared nanorods. After a series of tests, they found that nanorods showed the potential of an excellent photocatalyst for decomposing methyl orange; however, nanoflowers exhibited a preferable gas sensing performance. Recently, Wei et al. [20] synthesized $\mathrm{WO}_{3}$ nanorods, $\mathrm{WO}_{3}$ nanospheres, and $\mathrm{WO}_{3}$ nanoflowers by employing different reagents and hydrothermal times at the temperature of $180^{\circ} \mathrm{C}$. Additionally, the test results of $\mathrm{C}_{2} \mathrm{H}_{2}$ sensing properties indicated that the three examples all exhibited a good linear relationship between the response and the concentration of $\mathrm{C}_{2} \mathrm{H}_{2}$. Moreover, for exposure to $200 \mathrm{ppm} \mathrm{C}_{2} \mathrm{H}_{2}$ at $275{ }^{\circ} \mathrm{C}$, the response/recovery time of the nanoflowers was the shortest, and their response was about 15 , which was twice that of the nanorods and 1.5 times that of the nanospheres.

\subsubsection{The Morphology of Nanostructures}

In general, various methods for synthesizing nanomaterials can be grouped into three major categories: solid phase method, vapor phase method, and liquid phase method, according to the state of reactants, as shown in Table 3. Compared to other preparation methods, the liquid phase method has been studied widely because of its moderate reaction condition and good products with less defects and a better orientation. Therefore, in the next paragraphs, nanomaterials prepared in solvent condition will be discussed.

Table 3. The type and characters of preparation methods of nanomaterials.

\begin{tabular}{|c|c|c|c|}
\hline Method & Advantages & Disadvantages & Examples \\
\hline solid phase method & $\begin{array}{l}\text { simple synthesis process, } \\
\text { high yield, less pollution }\end{array}$ & $\begin{array}{l}\text { uneven distribution of } \\
\text { particle size, high } \\
\text { agglomeration }\end{array}$ & $\begin{array}{l}\text { ball milling method [21], shear } \\
\text { milling method [22] }\end{array}$ \\
\hline $\begin{array}{l}\text { vapor phase } \\
\text { method }\end{array}$ & $\begin{array}{l}\text { high purity powder, } \\
\text { small particle size, less } \\
\text { agglomeration }\end{array}$ & $\begin{array}{l}\text { high cost, high requirements } \\
\text { for instruments }\end{array}$ & $\begin{array}{l}\text { molecular beam epitaxy [23], } \\
\text { cathode sputtering [24] }\end{array}$ \\
\hline $\begin{array}{l}\text { liquid phase } \\
\text { method }\end{array}$ & $\begin{array}{l}\text { simple synthesis process, } \\
\text { controllable particle size }\end{array}$ & $\begin{array}{l}\text { low distribution, } \\
\text { low uniformity }\end{array}$ & $\begin{array}{l}\text { sol-gel method [25], } \\
\text { micro-emulsion method [26], } \\
\text { hydrothermal method [27] }\end{array}$ \\
\hline
\end{tabular}

The morphology is related to the formation of nanocrystals. In fact, the crystal formation process can be seen as the process of the solute precipitating out of the solution, of which there are three main steps: (1) Nucleation. For a certain solvent, any substance has a corresponding solubility, and when the solution is supersaturated, the solute can precipitate, forming crystal nuclei; (2) Growth. After nuclei form, they aggregate together and the degree of supersaturation becomes lower to allow nuclei formation again, and a balance is reached. Obviously, in this period, a shorter nucleation time leads to a more uniform grain size; (3) Ripening. Ostwald ripening is the period in which larger particles continue to grow, while the smaller particles become smaller and eventually dissolve, which does not happen until reactants are depleted as the reaction goes on. The concentration of solution and hydrothermal time are also important factors [28,29].

In the process, nucleation and growth should be separated to manufacture quantities of nanograins with a uniform size and good morphology, which can be accomplished by using high-reactivity reagents that are difficult to prepare and store. Due to the small size of nanomaterials, there are a large number of suspended and unsaturated chemical bonds on their surface and they are in a high-energy state, thus it is difficult to control their morphology and size [30]. On the contrary, preparing a "passivation layer" on the surface of the nucleated nanograin can satisfy this requirement in a moderate condition, which can be accomplished by surfactants. First of all, surfactants can aggregate orderly to form an aggregation such as a microemulsion, lipsomes, like a "micro-reactor", which indicates that they act as soft templates. Besides, at the early stage of the crystal formation process, surfactant molecules adsorbing on the crystal surface effectively prevent the agglomeration phenomenon and make nanomaterials more stable. Moreover, due to the different binding force between the surfactant 
molecules and different crystal surfaces, the former will accumulate on a specific crystal surface, which will slow down the growth rate of this crystal surface and thus play a role in guiding the direction of accumulation.

For example, Zou et al. [31] prepared three kinds of group samples by adding PVP (sample 1), PEG (sample 2), and no surfactant (sample 3), respectively, into $\mathrm{Fe}_{2}\left(\mathrm{MoO}_{4}\right)_{3}$ to detect ethanol. By choosing varied surfactants, a wide difference in the morphology and structure was generated among these samples-sample 1 consisted of uniform spherical nanoparticles, sample 2 was assembled by templates, and sample 3 was not regular and orderly, as shown in Figure 1. It can be seen that the surfactant is vital in the formation process of nanomaterials, and its dosage and species influence the results.

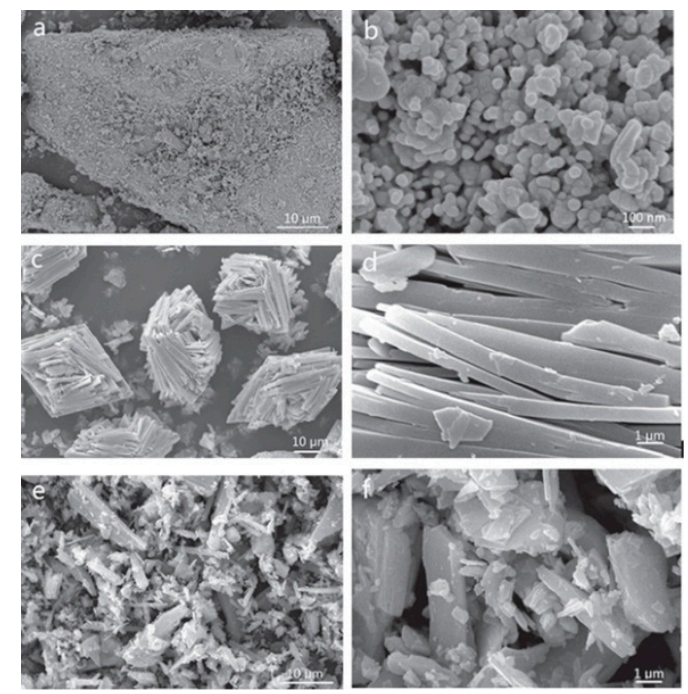

Figure 1. SEM images of (a,b) sample 1; (c,d) sample 2; and (e), (f) sample 3 [31].

Recently, Ren et al. [32] have reported an ordered mesoporous Fe doped $\mathrm{NiO}$ (Figure 2) based ethanol gas sensor with a high response, good selectivity, and short response/recovery time resulting from an excellent morphology and structure. In their study, polystyrene-b-poly was used to direct the growth of $\mathrm{NiO}$ and finally as-prepared $\mathrm{NiO}$ had a special dual mesoporous, high surface, as well as an interconnected crystalline structure.

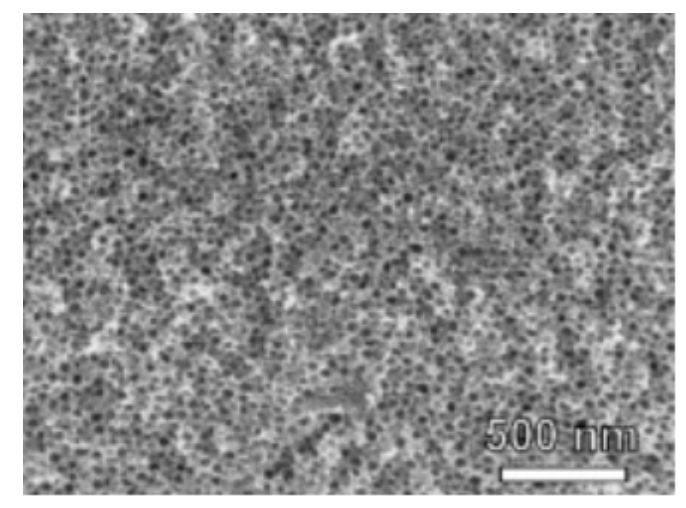

Figure 2. The SEM images of $\mathrm{mNiO}$ after calcination [32].

\subsection{Some Typical Structure and Morphology}

\subsubsection{Nanorod}

The high surface-to-volume ratio and effective transformation of the chemical species on the surface [33] prove that $1 \mathrm{D}$ materials are suitable candidates for gas sensing materials, of which 
the nanorod is a typical example. For example, Dewyani and co-workers [34] used a simple co-precipitation/digestion method to synthesize $\mathrm{Co}_{3} \mathrm{O}_{4}$ nanorods exhibiting excellent $\mathrm{CO}$ sensing properties. Especially, the response time was as short as $\sim 3-4 \mathrm{~s}$ and the recovery time was $\sim 5-6 \mathrm{~s}$; the operation temperature was comparatively low at $250{ }^{\circ} \mathrm{C}$. Their nanorods demonstrated prominent potential as $\mathrm{CO}$ sensors.

Generally, the growth of nanorods in the form of arrays needs a platform provided by the substrate that can be made from various materials. For instance, Narayanan et al. [35] reported an $\mathrm{H}_{2}$ sensor prepared by $\mathrm{ZnO}$ nanorods grown from the $\mathrm{ZnO}$ seed layer on microslide glass substrates [36] via a hydrothermal method. When exposed to $100 \mathrm{ppm}_{2}$, the sensor had a low operation temperature of $200^{\circ} \mathrm{C}$ and the response was found to be 0.7484 . As shown in Figure 3, Oh et al. [37] successfully fabricated vertically aligned $\mathrm{ZnO}$ nanorod arrays (the average diameter and length were $50 \mathrm{ppm}$ and 500 ppm, respectively) based electrochemical gas sensors. Their sensors could be obtained by introducing the $20 \mathrm{kHz}$ ultrasonic waves with a density of $39.5 \mathrm{~W} / \mathrm{cm}^{2}$ into the mixed solution (including $0.1 \mathrm{M}$ zinc nitrate hexahydrate and $0.01 \mathrm{M}$ hexamethylenetetramine), into which the substrate was immerged; the substrate was made from $\mathrm{Al}_{2} \mathrm{O}_{3}$ on which the Pt electrode was deposited, immediately followed by the deposition of a $\mathrm{Zn}$ thin film. As a result, at a relatively low operation of $250{ }^{\circ} \mathrm{C}$, the response was up to $824 \%$ when exposed to $100 \mathrm{ppb} \mathrm{NO}_{2}$, the detection concentration limit was as low as $10 \mathrm{ppb}$ and the response was faster than previous $\mathrm{NO}_{2}$ gas sensors, which was attributed to the well-aligned arrangement and high areal density in their opinion.
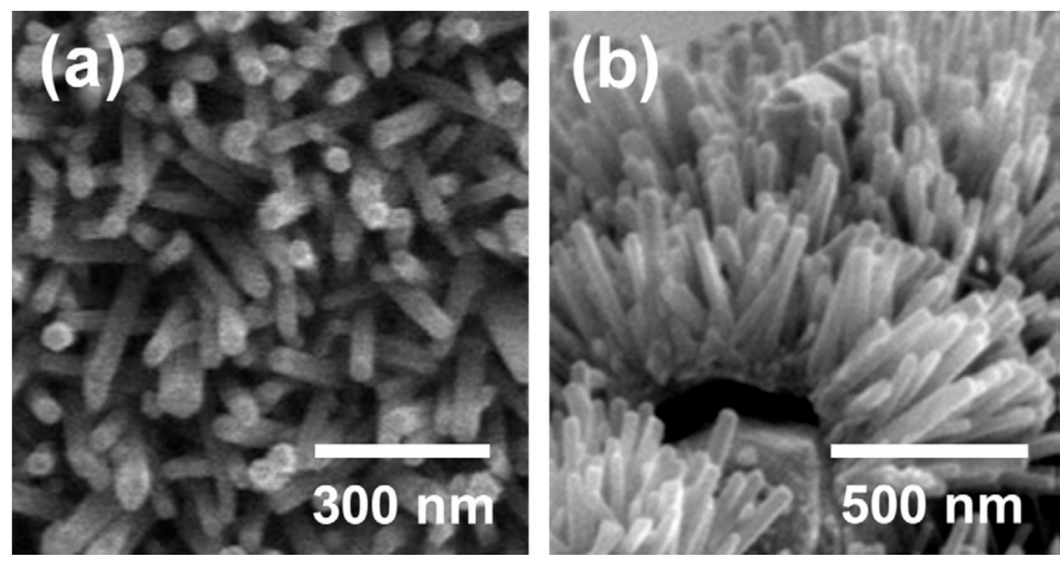

Figure 3. (a) Top view and (b) oblique view of SEM images of $\mathrm{ZnO}$ nanorod arrays [37].

However, some researchers have also proposed the substrate-free method. Long et al. [38] realized the synthesis of $\mathrm{WO}_{3}$ nanorod arrays under a simple hydrothermal condition without any substrate. Moreover, a series of measurements demonstrated that their nanorods have a good potential in $\mathrm{NH}_{3}$ sensing. The response can reach 8.3 while exposed to $50 \mathrm{ppm} \mathrm{NH}_{3}$ at $200{ }^{\circ} \mathrm{C}$.

\subsubsection{Nanosheet}

Due to abundant active sites and strong interconnections, nanosheets have more electron transfer channels, which can improve the reaction ratio between the materials and aimed gas [39]. However, researchers often use nanosheets to assemble other nanostructures or modify them.

$\mathrm{Li}$ et al. [40] synthesized hollow dodecahedrons built by $\mathrm{Co}_{3} \mathrm{O}_{4}$ nanosheets via a controllable two step self-templated process. Their sensitive materials not only had a good morphology, but were also suitable for being modified easily and uniformly. Furthermore, their experiments suggested that the optimal operation temperature was $100{ }^{\circ} \mathrm{C}$ for trimethylamine; after the modification of $\mathrm{PdO}$, the detection limit could reach $250 \mathrm{ppb}$ and the response time was as short as $4.5 \mathrm{~s}$. Zhang et al. [41] prepared $\mathrm{ZnO}$ microflowers assembled by nanosheets with the modification of Pd nanoparticles (as shown in Figure 4), which were applied to fabricate gas sensors exhibiting enhanced selectivity, 
a shorter response/recovery time, and a lower working temperature. Wang et al. [42] achieved the goal of detecting $\mathrm{H}_{2}$ at room temperature by considerng $\mathrm{FeOCl}$ nanosheets decorated with Au nanoparticles as the sensitive materials.

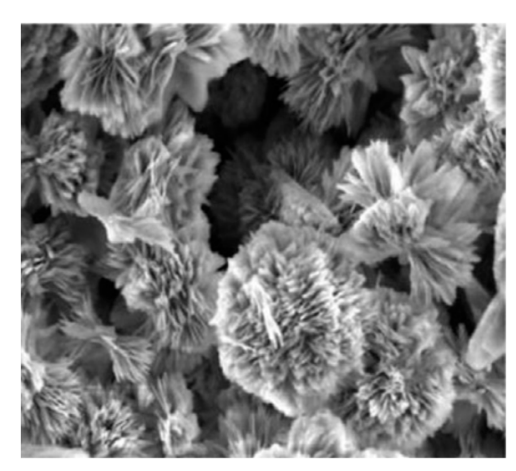

Figure 4. FESEM of $\mathrm{ZnO}$ micro flowers assembled by nanosheets [41].

\subsubsection{Micro-/Nano-Structured Hollow Spheres}

Hollow micro-/nano-structured materials have been investigated widely and applied to photocatalysts [43], the treatment of organic pollutants [44], the purification of plasmid DNA [45], and supercapacitors [46], etc. due to their advantages of a higher surface-to-volume ratio and shorter distance of charge transport [47], lower density, and better permeability [48] than solid structured materials. In this part, micro-/nano-structured hollow spheres will be mainly illustrated as typical 3D curved structures. Currently, hollow spheres can be synthesized by the hard-template method, soft-template method, sacrificial-template method, and template-free method. However, the first two technologies are time-consuming, so we will only talk about the latter two.

Han et al. [49] successfully synthesized $\mathrm{In}_{2} \mathrm{O}_{3}$ hollow spheres by using $\mathrm{Cu}_{2} \mathrm{O}$ as sacrificial templates, exhibiting short response/recovery time toward acetone gas. In their experiments, $\operatorname{In}_{2} \mathrm{O}_{3}$ was obtained by calcining $\mathrm{In}(\mathrm{OH})_{3}$, of which $\mathrm{In}^{3+}$ ions were from $\mathrm{InCl}_{3}$ as the indium source and the $\mathrm{OH}^{-}$ions were the products of the reaction between $\mathrm{Cu}_{2} \mathrm{O}$ and $\mathrm{S}_{2} \mathrm{O}_{3}{ }^{2-}$ ions as the coordinating etchant.

Although the template-assisted method has been widely adopted to fabricate hollow spheres, the cost of materials used as a template has urged searchers to develop the template-free method. Recently, Zhai et al. [50] reported an excellent triethylamine gas sensor, the sensitive materials of which were the $\mathrm{WO}_{3}$ hollow microspheres assembled by nanosheets via only a simple template-free hydrothermal process, as shown in Figure 5. They found that the sensor had a better response to triethylamine than other tested gases (the response toward $50 \mathrm{ppm}$ methylbenzene, $50 \mathrm{ppm}$ ethanol, $50 \mathrm{ppm}$ methanol, $50 \mathrm{ppm}$ acetone, $50 \mathrm{ppm}$ ammonia, $50 \mathrm{ppm}$ triethylamine is $\sim 2, \sim 2, \sim 2, \sim 4, \sim 1$ and $\sim 16$, respectively). Furthermore, the optimal operation temperature was $220^{\circ} \mathrm{C}$ and at this temperature, the sensor had a surprisingly short response time of only $1.5 \mathrm{~s}$ and a recovery time of $22 \mathrm{~s}$, far better than other triethylamine gas sensors. They mainly attributed the prominent sensitive performance to the many active sites provided by the numerously tiny sized pores, as well as the idea of using acidic metal oxide $\left(\mathrm{WO}_{3}\right)$ to detect basic gas (triethylamine). 


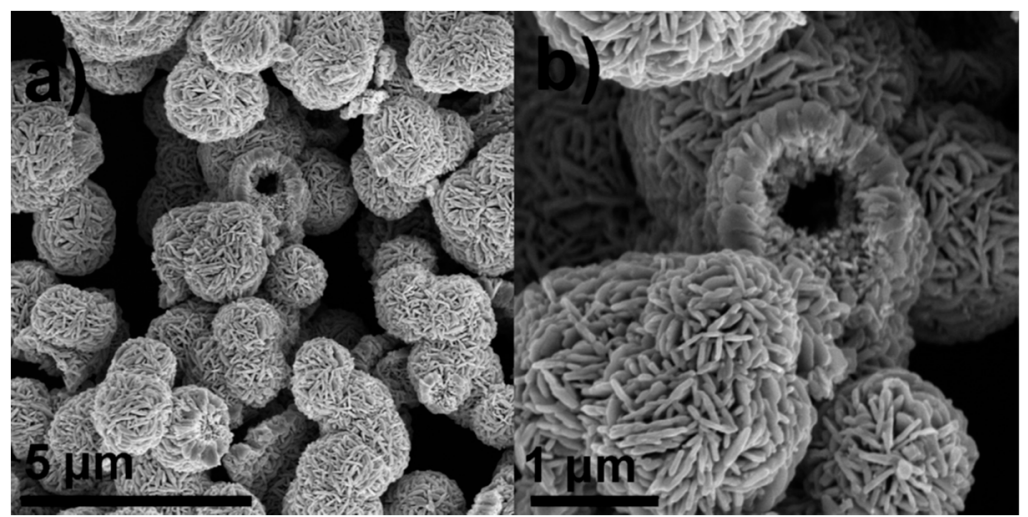

Figure 5. SEM image of $\mathrm{WO}_{3}$ hollow microspheres when the resolution is: (a) $5 \mu \mathrm{m}$ and (b) $1 \mu \mathrm{m}$ [50].

\subsubsection{Nanoflower}

Due to higher surface area and more available inter space, materials with flower-like nanostructures are attracting wide attention. Wang et al. [51] have fabricated gas sensors with $3 \mathrm{D} \mathrm{SnO}_{2}$ nanoflowers assembled by $2 \mathrm{D} \mathrm{SnO}_{2}$ nanosheets via a simple one-pot hydrothermal method at $90{ }^{\circ} \mathrm{C}$. In the experiment, $\mathrm{SnCl}_{2} \cdot 2 \mathrm{H}_{2} \mathrm{O}$ as tin resource was reacted with $\mathrm{NaOH}$ and $\mathrm{CTAB}$ was also added into the solution to assist the forming process of the nanostructure. As shown in Figure 6, they found that the nanostructure was related to the molar ratio $\mathrm{OH}^{-}$to $\mathrm{Sn}^{2+}$-with the molar ration increasing from $4 / 1$ to $10 / 1$, the thickness of nanosheets descended from $44.7 \mathrm{~nm}$ to $6.2 \mathrm{~nm}$; from $4 / 1$ to $8 / 1$, the beautiful grown nanoflowers could be seen and were varied when changing the molar ratio; when the molar ratio was higher, the petals of nanoflowers became smaller and finally, only the ovary was left. The gas sensing properties were tested in the ethanol ambient at a relatively low temperature of $240{ }^{\circ} \mathrm{C}$. When the concentration of ethanol gas was only $10 \mathrm{ppm}$, the gas sensor exhibited a considerable response of 2.8 that increased if the concentration was higher. Besides, the gas sensors showed a fast response to ethanol gas, including a response time within $25 \mathrm{~s}$ and a recovery time within $60 \mathrm{~s}$. Furthermore, other VOCs were also tested and the results indicated that the gas sensor could satisfy the practical requirements.
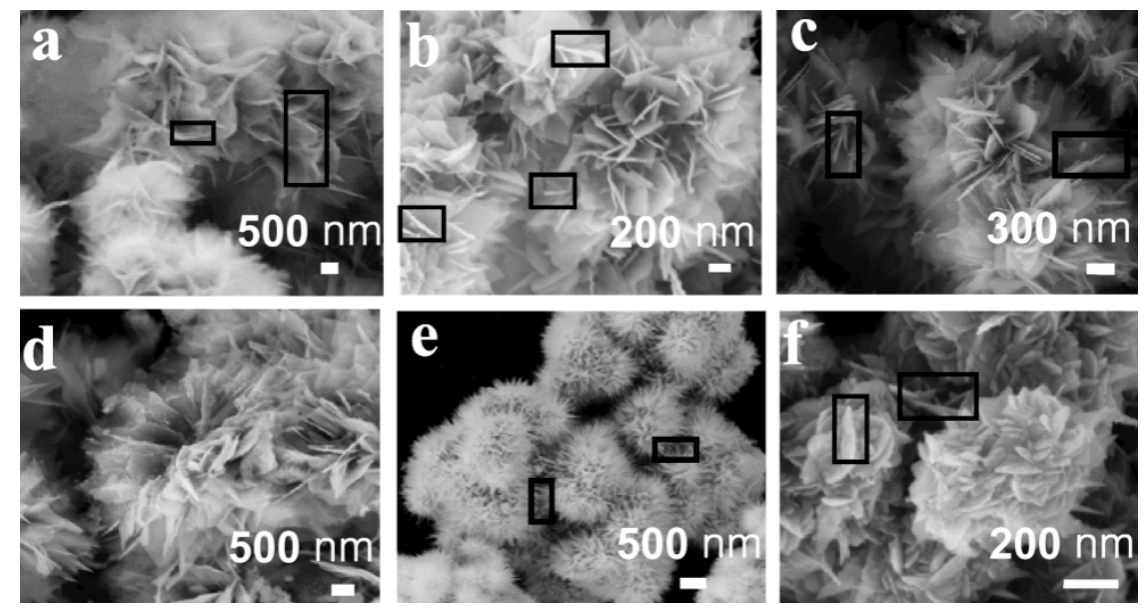

Figure 6. FESEM images of $\mathrm{SnO}_{2}$ nanoflowers when the molar ratio $\mathrm{OH}^{-}$to $\mathrm{Sn}^{2+}$ was (a) $4 / 1$, (b) $5 / 1$, (c) $6 / 1$, (d) $7 / 1$, (e) $8 / 1$, and (f) $10 / 1$, respectively [51].

Recently, Song et al. [52] reported $\mathrm{ZnO}$ nanoflowers (average diameter was 0.9 1 $\mu \mathrm{m}$ ) without other doping or decoration (Figure 7); however their nanomaterials exhibited a good selectivity to $\mathrm{NO}_{2}$ and a room temperature operation. Their detection limit was low, at $0.5 \mathrm{ppm}$, and a high response could be made to $1 \mathrm{ppm}$ under room temperature. Besides, the stability was also fairly good. 
Obviously, the excellent performance is related to the morphology, because uniform flower petals without aggregation can provide more sites for detecting $\mathrm{NO}_{2}$ molecules. Zhu et al. [53] synthesized $\mathrm{SnO}_{2}$ nanoflowers assembled by nanosheets (Figure 8). Toward $\mathrm{H}_{2}$ at $350{ }^{\circ} \mathrm{C}$, the response was 22 and the response/recovery time was $10 /$ less 10 s.

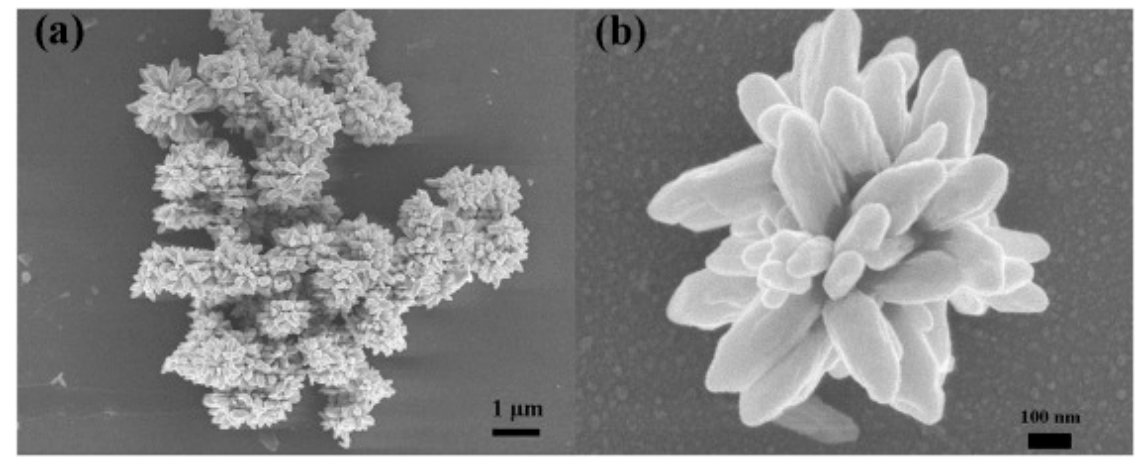

Figure 7. SEM images of $\mathrm{ZnO}$ nanoflowers with the resolution of (a) $1 \mu \mathrm{m}$ and (b) $100 \mathrm{~nm}$ [52].

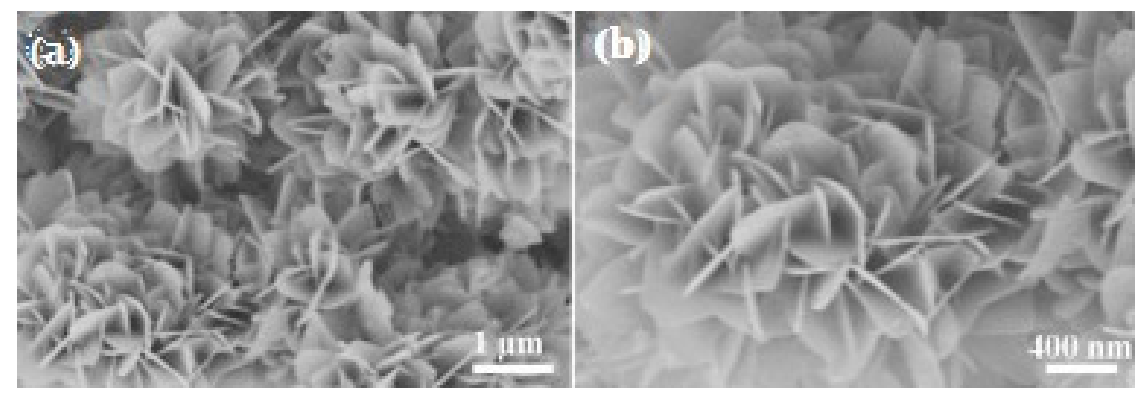

Figure 8. SEM images of $\mathrm{ZnO}$ nanoflowers with the resolution of (a) $1 \mu \mathrm{m}$ and (b) $400 \mathrm{~nm}$ [53].

\subsubsection{Core-Shell Structure}

Since the concept of a core-shell structure was proposed, nanomaterials with this structure have been widely applied to supercapacitor electrodes [54,55], photodetection [56], ions batteries [57,58], catalysts [59-61], and sensing [62]. Various nanostructured and various dimensional core-shell materials have been developed and exhibited satisfying performances in gas sensing, for example, nanoparticles [63], nanorods [64,65], nanofibers [66], nanobelts [67], nanowires [68], nanoneedles [69], micro-/nano-spheres [70,71], and nanotubes [72]. Different core/shell material systems could be formed by combining different materials, such as metal oxide/metal oxide [65], noble metal/metal oxide [73], metal oxide/noble metal [63], noble metal/noble metal [74], metal oxide/organics [75,76], and inorganics/metal oxide [77], etc.

It has been demonstrated that the application of a core-shell can further improve gas sensing compared to a conventional nanostructure. For example, Park et al. [78] synthesized $\mathrm{Ga}_{2} \mathrm{O}_{3} / \mathrm{WO}_{3}$ core-shell nanostructures composed of nanobelts, nanoparticles, and nanowires through thermal evaporation $\mathrm{Ga}_{2} \mathrm{~S}_{3}$ powders followed by thermal evaporation $\mathrm{WO}_{3}$ powders and tested the gas sensing properties of their sensors. Compared to pristine $\mathrm{Ga}_{2} \mathrm{O}_{3}$ nanostructured gas sensors, when ethanol was the aimed gas, their sensors showed a stronger response, which can be illustrated by the surface depletion layer method and the potential barrier-controlled carrier-transport method; at the same time, the total sensing time (that refers to response time adding up to recovery time) was $\sim 50 \mathrm{~s}$ faster than that of pristine sensors and the operation temperature had a reduction of $100{ }^{\circ} \mathrm{C}$; in addition, their sensors had an enhanced selectivity toward ethanol gas. Runa et al. [79] prepared well-performing $\mathrm{NO}_{2}$ gas sensors, of which the sensitive materials were flower-like core-shell nanostructured $\mathrm{ZnO} / \mathrm{ZnFe}_{2} \mathrm{O}_{4}$ via a two step hydrothermal method under mild reaction conditions. Through the gas sensing test, they found that their sensors had better performances than pure $\mathrm{ZnO}$ sensors toward $\mathrm{NO}_{2}$ gas and 
benefitted from the flower-like core-shell structure and the p-n heterojunction formed at the interface between $\mathrm{ZnO}$ and $\mathrm{ZnFe}_{2} \mathrm{O}_{4}$.

For this structure, the thickness of the shell exerts an apparent influence on the gas sensing properties. Uddin et al. [80] synthesized $\mathrm{Pd}-$ core/ $\mathrm{Pt}$ - shell nanotubes structured materials by a facile two step hydrothermal process and further investigated the influences of $\mathrm{Pt}$ film thickness on fast response $\mathrm{H}_{2}$ sensing properties. In their experiments, the shell thickness was controlled by various growth periods and the test results suggested that the optimal Pt coverage thickness is ultimately $\sim 5-10 \mathrm{~nm}$. Under optimal conditions, the working temperature was as low as $150^{\circ} \mathrm{C}$.

\section{Doping with Two-Dimensional Nanomaterials}

In 2004, Geim's research group prepared graphene that could exist stably, which broke the previous consensus that two-dimensional materials could not exist independently. With the in-depth study of the energy band structure and various properties of graphene, two-dimensional materials represented by graphene have gradually became a research hotspot. In this section, graphene, $\mathrm{MoS}_{2}$, and black phosphorus will be introduced as examples.

\subsection{Graphene}

Graphene refers to a single layer of graphite atoms. Its theoretical thickness is only $0.35 \mathrm{~nm}$, and its light transmittance can reach $97.7 \%$. It is the thinest material known at present, but it is also the material with the greatest strength known at present. Its plane is composed of six carbon atoms of a cellular structure, of which each carbon atom is linked together to three other adjacent carbon atoms by $\sigma$ bonds and the rest of the electrons not bonded form $\pi$ bonds, perpendicular to the graphene surface in order that electrons can move freely, so it has excellent electrical conductivity and its electron mobility is as high as $250,000 \mathrm{~cm}^{2} /(\mathrm{V} \cdot \mathrm{s})$ [81-83]. In addition, graphene with a two-dimensional structure can be curled into fullerenes with a zero-dimensional structure or carbon nanotubes with a one-dimensional structure, or it can be stacked into graphite with a three-dimensional structure to form a complete carbon family (Figure 9) [84]. Due to its excellent properties, graphene and its ramifications, such as reduced graphene oxide (rGO), have been used for catalysts [85], sensing [86], supercapacitors [87], lithium batteries [88], and so on. Additionally, recently, rGO has been regarded as a promising material for modifying MOS to obtain improving gas sensing properties [89-91].

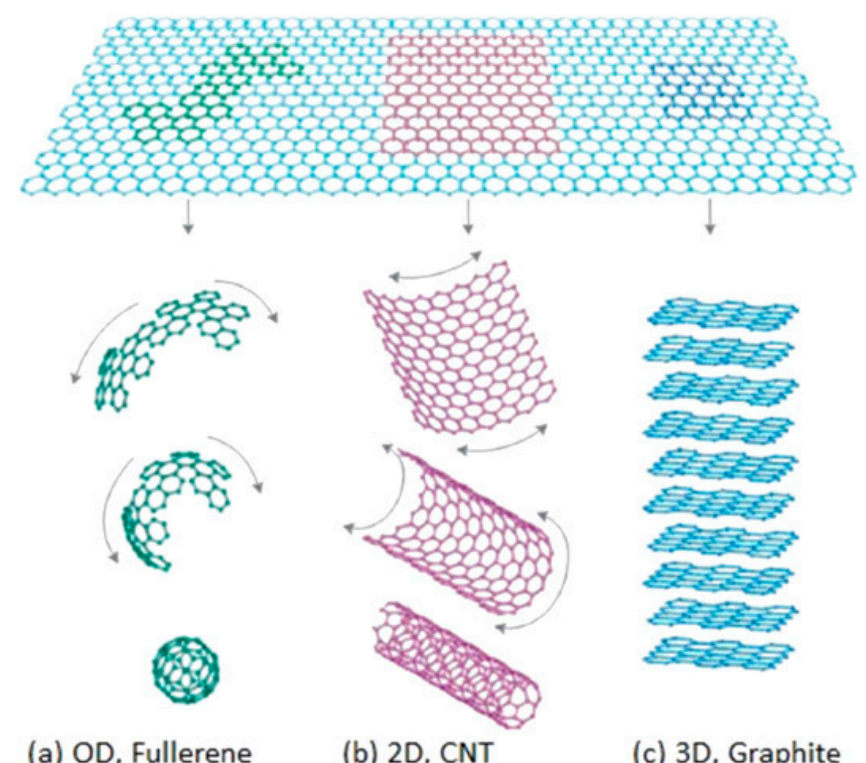
(a) OD, Fullerene
(b) 2D, CNT
(c) 3D, Graphite

Figure 9. Graphene nanosheets can be transformed to (a) fullerene, (b) carbon nanotube, and (c) graphite [84]. 
$\mathrm{Li}$ and his co-workers [92] synthesized a $\mathrm{Zn}_{2} \mathrm{SnO}_{4}(\mathrm{ZTO}) / \mathrm{rGO}$ nanocomposite showing better ethanol sensing properties than bare $\mathrm{Zn}_{2} \mathrm{SnO}_{4}$ and investigated the influence of the ratio between $\mathrm{ZTO} / \mathrm{rGO}$. Figure 10 shows the response of four kinds of materials to $100 \mathrm{ppm}$ ethanol, and it can be seen that although the operation temperature did not reduce, the response had an obvious improvement, and the best ratio between $\mathrm{ZTO} / \mathrm{rGO}$ was 8:1 (in the figure, nZTO/rGO means that ZTO:rGO $=\mathrm{n}: 1$ ). Besides, the mechanism was further explained as follows. First, higher surface-to-volume and more active sites for gas adsorption were obtained by avoiding the aggregation phenomenon of ZTO nanoparticles by doping with rGO (as shown in Figure 11). Comparing Figure 11 $\mathrm{b}$ and $\mathrm{c}$, it can be clearly seen that doping with rGO prevented the aggregation of ZTO nanoparticles to a great extent. Furthermore, the interaction between ZTO and rGO generated numerous defects and vacancies, which also provided more active sites. Additionally, because rGO has a better conductivity, its introduction can improve the electric properties of ZTO and further facilitate electronic migration.

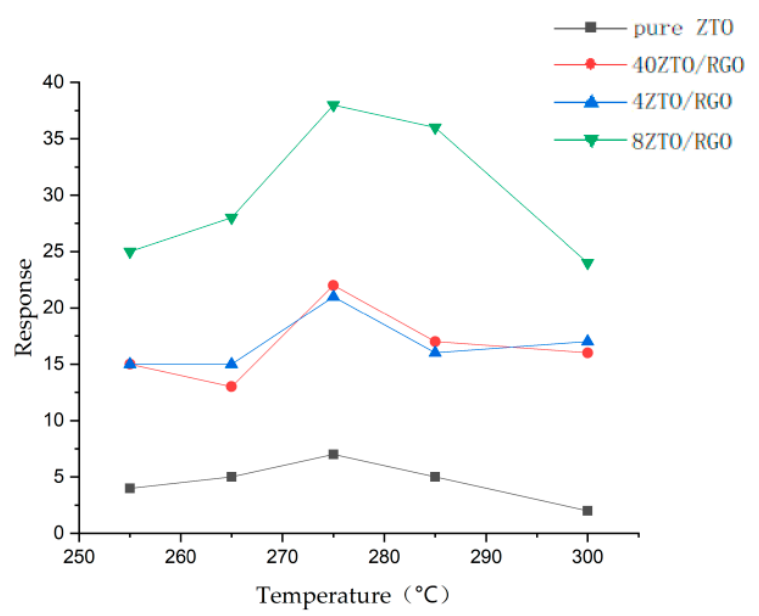

Figure 10. The response of four kinds of sample to to $100 \mathrm{ppm}$ ethanol.
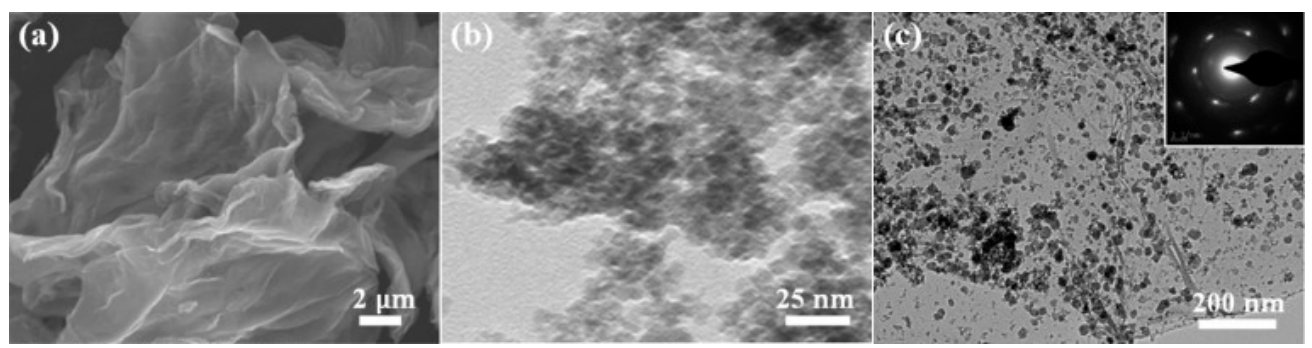

Figure 11. SEM images of (a) rGO, (b) ZTO nanoparticles, and (c) $8 \mathrm{ZTO} / \mathrm{rGO}$ [92].

\section{2. $\mathrm{MoS}_{2}$}

Molybdenum disulfide $\left(\mathrm{MoS}_{2}\right)$, a typical material of transition metal dichalcogenides, is a black powder with metallic luster and is the main component of molybdenite. Its chemical property is very stable, thus it is insoluble in organic solvent, water, and dilute acid, but can react with aqua regia, hot sulfuric acid, and hot nitric acid. Different from the zero band gap of graphene, $\mathrm{MoS}_{2}$ has a wider band gap [93-95]. Because of specific physical and chemical properties, $\mathrm{MoS}_{2}$ is applied to a number of fields, such as photoelectrical detecting [96], gas sensing [97], catalysts [98,99], energy storage [100], lubricant [101], etc.

Figure 12 shows the specific structure of $\mathrm{MoS}_{2}$ [93]. $\mathrm{MoS}_{2}$ consists of vertically stacked layers, each of which is formed by covalently bonded $\mathrm{Mo}-\mathrm{S}$ atoms, and each neighboring layer is connected by relatively weak van der Waals forces. These weak van der Waals interactions allow gas molecules to infiltrate and diffuse freely between the layers. In this way, the resistance of $\mathrm{MoS}_{2}$ can dramatically change with the adsorption and diffusion of gas molecules within the layers. Compared to traditional 
semiconductor gas sensing materials, $\mathrm{MoS}_{2}$ has several specific advantages, including a larger surface-to-volume ratio, higher adsorption efficiency, and more crystal defects, which lead to its significant position in the field of gas sensing. For example, Luo et al. [102] successfully synthesized Pt-activated $\mathrm{MoS}_{2} / \mathrm{TiO}_{2}$ that can detect hydrogen at $100{ }^{\circ} \mathrm{C}$. Obviously, the excellent gas sensing properties were related to the heterojunction between $\mathrm{MoS}_{2}$ and $\mathrm{TiO}_{2}$ and the decoration with Pt.

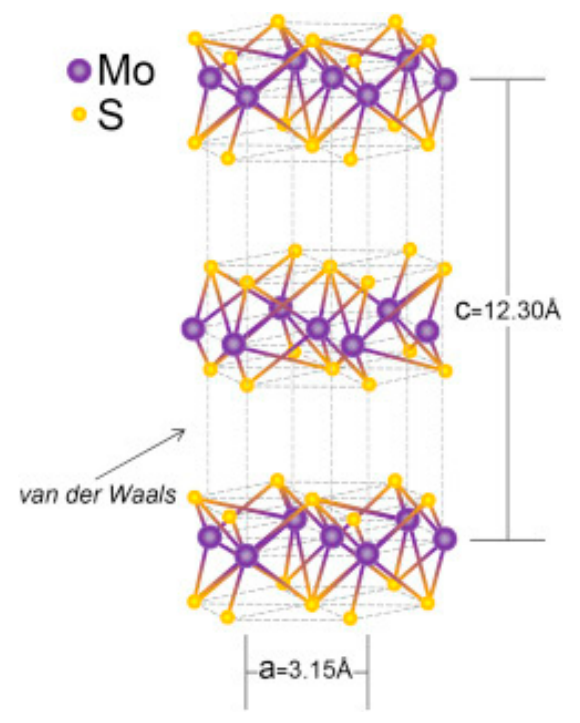

Figure 12. Schematic diagram for the structure of $\mathrm{MoS}_{2}$ [93].

However, $\mathrm{MoS}_{2}$ is insensitive to gas composed of nonpolar molecules, to which applying noble metal as a catalyst is an effective approach. Baek et al. [103] have reported a simple method for fabricating $\mathrm{H}_{2}$ sensors with monolayer $\mathrm{MoS}_{2}$ functionalized by Pd. Sensors were prepared by some simple steps including dripping $\mathrm{MoS}_{2}$ on $\mathrm{SiO}_{2}$ substrate, the deposition of Pd nanodots on the forming $\mathrm{MoS}_{2}$ nanosheet, and finally fixing electrodes on the surface. With exposure to $1 \% \mathrm{H}_{2}$, the $\mathrm{MoS}_{2}$ sensors had no reaction. In contrast, the performances, including good repeatability, a short response time of $13.1 \mathrm{~min}$, a short recovery time of $15.3 \mathrm{~min}$, and a low detection limit of $500 \mathrm{ppm}$, of Pd-functionalized $\mathrm{MoS}_{2}$ sensors displayed a huge improvement due to the formation of $\mathrm{PdH}_{x}$ on the $\mathrm{Pd}$ nanodots while exposed to $\mathrm{H}_{2}$. Besides, $\mathrm{MoS}_{2}$ is apt strongly to oxidizing in air, limiting its application in gas sensing.

\subsection{Black Phosphorus}

Black phosphorus (BP), the most stable allotrope of phosphorus, was first fabricated by Bridgman in 1914 [104]. However, there was a long period where BP did not receive much attention until phosphorene (monolayer phosphorus) was successfully prepared for the first time by mechanical exfoliation in 2014 [105], which can be regarded as the beginning of its extensive study and application. Similar to graphite, BP also comprises separate layers bonded to each other by weak van der Waals forces. The unique anisotropy crystal structure (Figure 13) means that BP has various specific properties and advantages [106]. In the latter part, the black phosphorus what we talk about only refers to phosphorene rather than bulk phosphorus. 
(a)

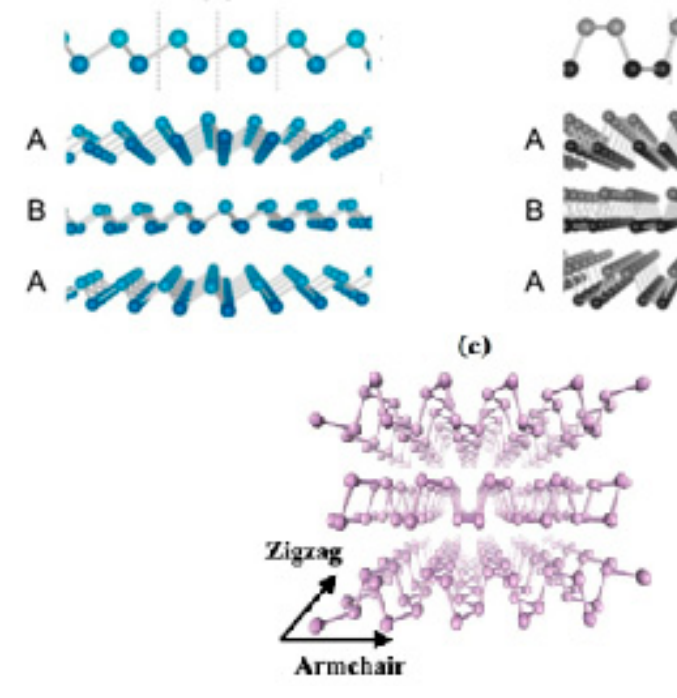

(b)
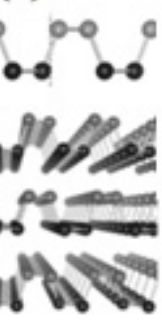

Figure 13. (a) Zigzag direction, (b) armchair direction, and (c) straight view of black phosphorus.

BP possesses a moderate and direct band gap bridging the gap between graphene and $\mathrm{MoS}_{2}$. Besides, its comparatively large carrier mobility $\left(600 \sim 1000 \mathrm{~cm}^{2} /(\mathrm{V} \cdot \mathrm{s})\right.$ ) and moderate on/off ratio $\left(10^{3} \sim 10^{5}\right)$ bridge the gap between graphene with an extraordinarily high carrier mobility $\left(10^{3} \sim 10^{5} \mathrm{~cm}^{2} /(\mathrm{V} \cdot \mathrm{s})\right)$, as well as quite small on/off ratio $(5 \sim 44)$, and TMDs with a low carrier mobility $\left(10 \sim 500 \mathrm{~cm}^{2} /(\mathrm{V} \cdot \mathrm{s})\right)$, as well as inversely large on/off ratio $\left(10^{4} \sim 10^{8}\right)$ [107]. The value of these electrical parameters above are relevant to layers of BP. Owing to excellent properties including the optical property, thermal property, mechanical property, biocompatibility, etc. [108], apart from the electrical property, BP has been broadly applied to FETs [109-111], batteries [112,113], photodetectors [114], gas sensors [115], protease detection, and inhibitor screening [116].

Two-dimensional materials are quite ideal candidates for gas sensing, thus BP is not an exception and has even better performances resulting from higher surface-to-volume because of its puckered crystal structure. For example, Han et al. [117] fabricated $\mathrm{TiO}_{2}$ doped with $\mathrm{BP}$ via the sol-gel method. Through their experiments, they found that $5 \mathrm{~mol} \%$ was the optimal concentration and an obvious response could happen at $\sim 116^{\circ} \mathrm{C}$, as shown in Figure 14 . BP as a dopant could not only provide more active sites, but also form a heterojunction with $\mathrm{TiO}_{2}$, which facilitated gas sensing properties.

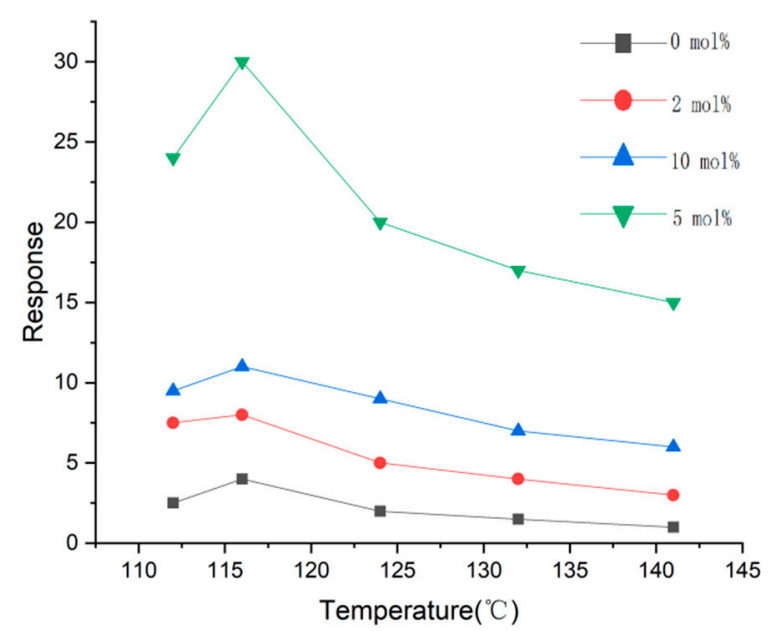

Figure 14. Sensitivity of $\mathrm{TiO}_{2} / \mathrm{BP}$ (varied concentration) to $100 \mathrm{ppm}$ oxygen gas. 


\section{Decorating with Noble Metal Nanoparticles}

The term noble metal often refers to eight kinds of metal elements, such as $\mathrm{Au}, \mathrm{Ag}, \mathrm{Ru}, \mathrm{Rh}, \mathrm{Pd}$, $\mathrm{Os}$, Ir, and Pt, most of which have gorgeous luster and a strong chemical stability. Recently, numerous researches have verified the fact that decoration with noble metal particles facilitates sensors' sensitive performances, including a higher response, better selectivity, and shorter response/recovery time, etc. $[118,119]$.

In this paragraph, $\mathrm{ZnO}$, a typical n-type semiconductor, will be used as an example to illustrate the working mechanism of this approach. While exposed to air, zinc oxide could adsorb the oxygen molecules on its surface, and these adsorbed oxygen molecules could then trap free electrons from the conduction band of $\mathrm{ZnO}$ and consequently transform to $\mathrm{O}_{2}{ }^{-}, \mathrm{O}^{-}$, and $\mathrm{O}^{2-}$ by ionizing (as shown in Equations (1)-(4) [120-122]), which caused the formation of the depletion layer on the sensitive material's surface, making the conductive channel narrow and the resistance increase.

$$
\begin{gathered}
\mathrm{O}_{2} \text { (gas) } \rightarrow \mathrm{O}_{2} \text { (ads) } \\
\mathrm{O}_{2} \text { (ads) }+\mathrm{e}^{-} \rightarrow \mathrm{O}_{2}^{-} \\
\mathrm{O}_{2}^{-}+\mathrm{e}^{-} \rightarrow 2 \mathrm{O}^{-} \\
\mathrm{O}^{-}+\mathrm{e}^{-} \rightarrow \mathrm{O}^{2-} \\
2 \mathrm{CO}+\mathrm{O}_{2}^{-} \rightarrow 2 \mathrm{CO}_{2}+\mathrm{e}^{-} \\
\mathrm{CO}+\mathrm{O}^{-} \rightarrow \mathrm{CO}_{2}+\mathrm{e}^{-} \\
\mathrm{CO}+\mathrm{O}^{2-} \rightarrow \mathrm{CO}_{2}+2 \mathrm{e}^{-}
\end{gathered}
$$

When reduced gas is diffused, it will be oxidized by oxygen ions on the surface, so the captured electrons will be released into the conduction band of $\mathrm{ZnO}$ (as shown in Equations (5)-(7) [120-122]). As a result, the thickness of the electron depletion layer of $\mathrm{ZnO}$ becomes thinner, the concentration of free electrons in $\mathrm{ZnO}$ increases, and the resistance decreases [123-125].

Generally, two mechanisms can illustrate the role of noble metal in enhancing gas sensing properties, i.e., chemical sensitization and electronic sensitization: (1) Chemical sensitization [126,127]. Oxygen molecules are prone to adsorbing on noble metal particles, hence these excessive molecules will further "spill" onto the surface of $\mathrm{ZnO}$, increasing the number of reactive oxygen molecules involved in the reaction process and at the same time, providing more active sites, as shown in Figure 15 [127]; (2) Electronic sensitization [128-130]. Because zinc oxide has a lower work function than noble metal, when noble metal particles are decorated on the surface, a portion of free electrons will transfer from $\mathrm{ZnO}$ to those particles so that Schottky junctions will be formed at the contact interface, which can further decrease the concentration of free electrons in the conduction band of $\mathrm{ZnO}$ and deepen the thickness of the electron depletion layer. Besides, noble metal oxides are a big acceptor of oxygen; while making contact with reducing gas, they are also reduced to noble metal, which contributes a bunch of electrons. Also, the modification of noble metals can obviously shift the Fermi level of $\mathrm{ZnO}$ and reduce the required energy for electron transition, as shown in Figure 16 [131]. 


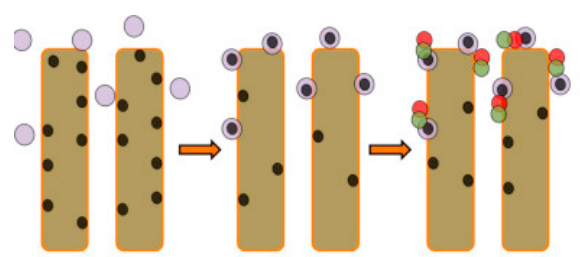

a)

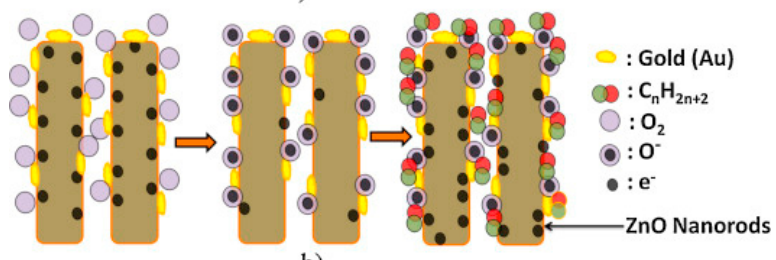

b)

Figure 15. Schematic diagram of alkanes sensing of (a) pure $\mathrm{ZnO}$ nanorods and (b) Au functionalized nanorods [127].

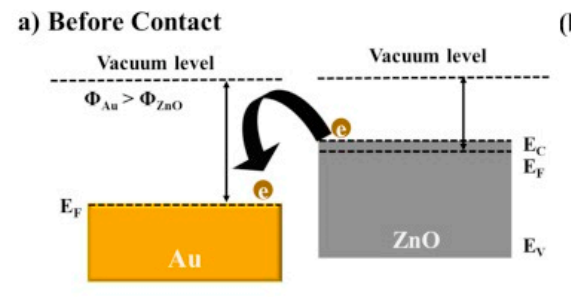

(b) After contact in Air

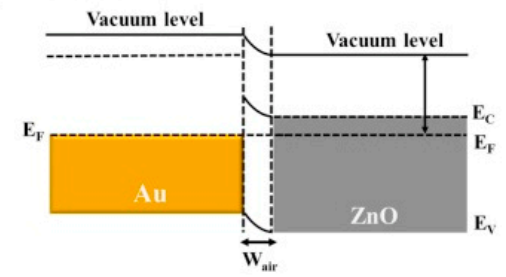

(c) After contact in $\mathrm{NO}_{2}$

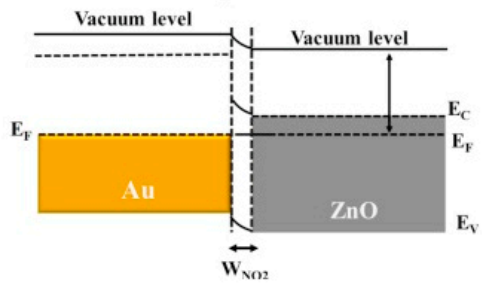

Figure 16. Schematic diagram of energy level of Au functionalized $\mathrm{ZnO}$ (a) before contact with air, (b) during contact with air, and (c) during contact with $\mathrm{NO}_{2}$ [131].

Noticeably, different effects will be produced if different kinds of noble metal particles are employed. Esfandiar et al. [132] reported that $\mathrm{TiO}_{2}$ nanoparticles decorated by $\mathrm{Pd}$ and $\mathrm{Pt}$ had an improved sensitivity toward hydrogen than pure $\mathrm{TiO}_{2}$. In their experiment, they first synthesized $\mathrm{TiO}_{2}$ nanoparticles via the sol-gel method, and then used the chemical reduction method to decorate the hybrid structures with Pd and Pt, and the results of gas sensitivity are shown in Figure 17. From the figure, it can be seen that the decoration of $\mathrm{Pd}$ or Pt both could improve the sensitive performances, but Pd had a better function. Particularly, the decoration of Pd nanoparticles dramatically increased the sensitivity and shortened the response time determined by the $\mathrm{H}_{2}$ adsorption rate, which indicates opinions that are referred to above.

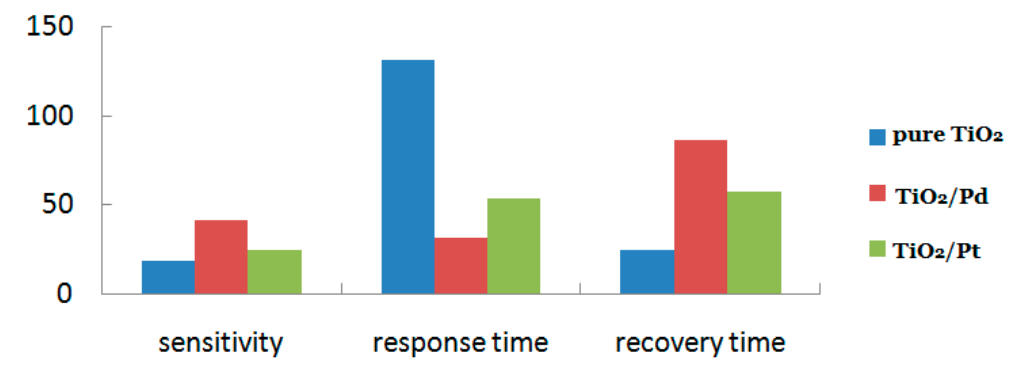

Figure 17. Results of different samples toward $500 \mathrm{ppm} \mathrm{H}_{2}$ at $180^{\circ} \mathrm{C}$ in Esfandiar's experiments. 
The concentration of noble metal particles loaded on the surface of sensitive materials is also an important factor, because the sensitivity of the gas sensor is not only related to the chemical reaction between material and gas, but is also affected by gas transport and utilization. It can be easily understood that with the continuous increasing of particles, the agglomeration phenomenon will happen, and a lot of wasted active sites and the too thick layer of noble metal particles will produce a negative influence on gas transport. Arunkumar et al. [123] prepared a highly selective and sensitive $\mathrm{CO}$ gas sensor by decorating Au nanoparticles on a zinc oxide $(\mathrm{ZnO})$ nanostructure through the solution impregnation technique. They found that the response was higher with the changing concentration of Au nanoparticles from $1 \mathrm{wt} \%$ to $3 \mathrm{wt} \%$ and would decrease if more Au nanoparticles were applied.

In addition, the synergistic effect means that a bimetallic catalyst is a preferable option. In the past years, bimetallic catalyst systems which have been frequently investigated are Au-Pt [133-135], Pt-Pd [136-140], Au-Pd [141,142], Au-Ag [143], etc. Kim et al. [144] have reported an acetone gas sensor with excellent sensitive performances. They synthesized $\mathrm{WO}_{3}$ nanorods by the thermal evaporation method, and these nanorods were then submerged into the mixed solution composed of acetone, $\mathrm{HAuCl}_{4}$, and $\mathrm{PdCl}_{2}$ preceding UV irradiation and annealing. At $300{ }^{\circ} \mathrm{C}$, the sensitive properties of four samples were examined, including pure $\mathrm{WO}_{3}, \mathrm{Au}-\mathrm{WO}_{3}, \mathrm{Pd}-\mathrm{WO}_{3}$, and $\mathrm{AuPd}-\mathrm{WO}_{3}$ (as shown in Figure 18). From Figure 18, it can be seen that $\mathrm{WO}_{3}$ nanorods after being decorated with noble metals and the synergistic effect between two kinds of noble metals can obtain a better result. Although the response and response time were both improved, an obvious change did not occur with respect to the recovery time.
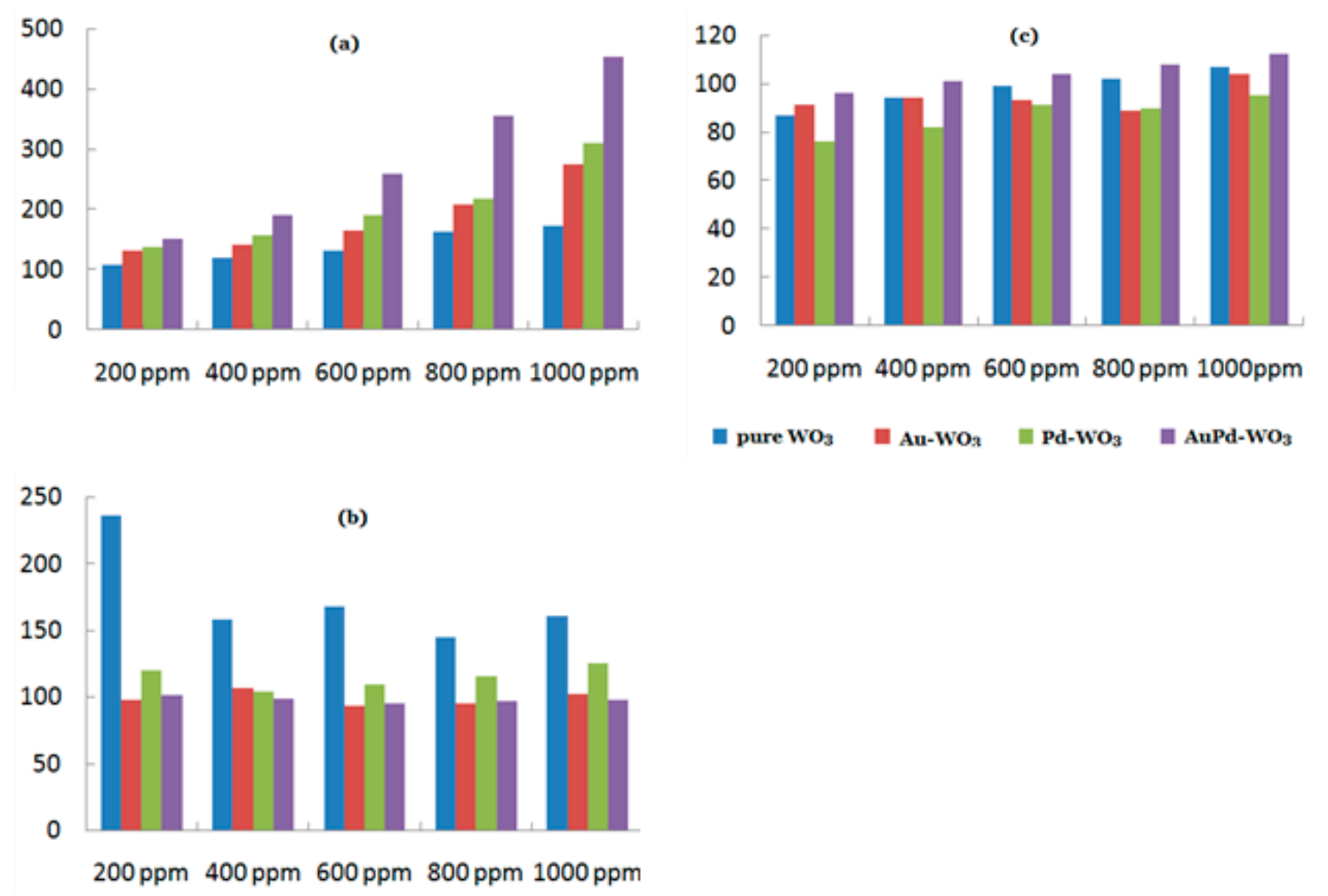

Figure 18. (a) Response, (b) response time, and (c) recovery time of different samples toward acetone at $300{ }^{\circ} \mathrm{C}$.

\section{Forming the Heterojunction}

The heterojunction refers to the contact transition region formed at the interface between two semiconductors with different band gap widths. As we all know, semiconductors consist of p-type semiconductors (hole concentration $>$ free electron concentration, such as $\mathrm{Cu}_{2} \mathrm{O}, \mathrm{NiO}, \mathrm{VO}_{2}$ ) and n-type 
semiconductors (free electron concentration $>$ hole concentration, such as $\mathrm{ZnO}, \mathrm{Ta}_{2} \mathrm{O}_{5}$ ). Therefore, a heterojunction can be classified as a homogeneous heterojunction (n-n heterojunction and p-p heterojunction) and heteromorphic heterojunction (p-n heterojunction). Heterojunctions may occur in various structures, such as nanoparticles [145], nanosheets [146], flower-like hollow microspheres [147], core-shell structured nanofibers [148]/nanorods [149]/nanoneedles [150], etc.

Due to the different chemical parameters and physical parameters, including band structure, dielectric constant, lattice constant, and electron affinity, etc. of the two materials, the mismatch phenomenon at the interface endows the heterojunction with a lot of novel properties, which have been attracting much research on heterogeneous materials and devices. In the past, heterojunctions have made tremendous contributions to photocatalysts [151-153], solar cells [154], photovoltaic applications [155], photoelectrochemical applications [156-158], diode devices [159], etc. The unique properties of a heterojunction also make it an effective and practical candidate for gas sensors.

\section{1. $n-n$ Heterojunction}

In 2012, Sharma and his colleagues [160] used sensors made from $\mathrm{SnO}_{2}$ film loaded with $\mathrm{WO}_{3}$ micro-discs to detect trace $\mathrm{NO}_{2}$ gas and obtained a good result. Compared to pure $\mathrm{SnO}_{2}$ or $\mathrm{SnO}_{2}$ and $\mathrm{WO}_{3}$ compounds, their sensors had a higher response of 54,000 and lower optimal temperature of $100{ }^{\circ} \mathrm{C}$, as well as a fast response/recovery time of $67 \mathrm{~s} / 17 \mathrm{~min}$. They supposed that the space charge region caused by $n-n$ heterojunctions played an important role in the enhancement of $\mathrm{NO}_{2}$ sensing properties.

\section{2. $p$ - $p$ Heterojunction}

Alali et al. [161] synthesized $\mathrm{CuO} / \mathrm{CuCo}_{2} \mathrm{O}_{4}$ nanotubes via the electrospinning method and a subsequent heat treatment process. Those nanotubes containing the p-p heterojunction could detect n-propanol at room temperature and showed a response of 14 and a short response/recovery time of $6.3 \mathrm{~s} / 4.1 \mathrm{~s}$. At the same time, those nanotubes also had a better selectivity toward n-propanol than other gases and a good stability.

Tai et al. [162] developed an $\mathrm{NH}_{3}$ gas sensor working at room temperature by using the microstructure silicon arrays that polyaniline nanorods were deposited on. The unique 3D structure and the formation of $\mathrm{p}$-p heterojunction brought huge advantages in $\mathrm{NH}_{3}$ sensing.

\section{3. $p$ - $n$ Heterojunction}

Gong and his colleagues [163] reported an ultrasensitive $\mathrm{NH}_{3}$ gas sensor from n-type semiconductor $\mathrm{TiO}_{2}$ microfibers attached by a p-type polymer polyaniline nanograin for the first time. According to their test results, the detection limit was as low as $50 \mathrm{ppt}$ in air and under this condition, a high response could also be obtained. Noticeably, there had never been reports about tens of parts-per-trillion levels of $\mathrm{NH}_{3}$ gas detection before their work.

Huang et al. [164] demonstrated a special heterojunction, i.e., an n-p-n heterojunction, existing in the contact region between $\mathrm{ZnO}$ film and $\mathrm{SnO}_{2}$ nanorods. In their experiment, their sensitive materials could be obtained by the preparation of pristine $\mathrm{SnO}_{2}$ nanorod arrays via the plasma-enhanced CVD method at low temperature and then spin coating in the zinc acetate ethanol solution to form one $\mathrm{ZnO}$ layer on the surface of nanorods. Toward $100 \mathrm{ppm} \mathrm{H}_{2}$-one typical reduced gas, totally opposite to the n-type sensing response of pristine $\mathrm{SnO}_{2}$ sensors, an abnormal p-type sensing response occurred in terms of their sensors and the maximum response of 18.4 could be obtained at the optimal operation temperature of $350{ }^{\circ} \mathrm{C}$. However, when other reduced gas, including $\mathrm{CO}, \mathrm{NH}_{3}$, and $\mathrm{CH}_{4}$, was injected, a reverse trend was displayed for the response to $\mathrm{H}_{2}$. Additionally, they also found that the response type was related to the concentration and the humidity. The formation of the $\mathrm{n}-\mathrm{ZnO} / \mathrm{p}-\mathrm{Zn}-\mathrm{O}-\mathrm{Sn} / \mathrm{n}-\mathrm{SnO}_{2}$ heterojunction together with the unique nanostructure contributed to the potential application of exclusive $\mathrm{H}_{2}$ sensors. 


\section{Conclusions}

In this review, four kinds of measures tackling issues restricting the application and performance of gas nanosensors are mainly introduced, including controlling the nanostructure, doping with two-dimensional nanomaterials, decorating with noble metal nanoparticles, and forming the heterojunction.

Generally, a better nanostructure and morphology is very important to gas sensing properties and can even be regarded as the base of an excellent performance, which can be accomplished by surfactant. However, additional surfactant leads to the influence of humidity on gas sensing, which is acceptable. Because the enhancing effect caused by the nanostructure is finite, to further improve the sensing properties and satisfy more requirements, additional decoration or dope are developed and combined with an ordered structure and morphology. Compared to other methods, the preparation process of 2D nanomaterials is harder, the cost is higher, the period is longer, and they are prone to be oxidized in air, which is difficult to solve, so the other two methods are preferred by researchers due to their comparatively moderate preparation condition and proven technology. Noble metal has been employed widely due to its unique performance and plays an important role in gas sensors. Besides, the high price can be compensated for by their excellent enhancing effect. Due to the distinction of the performance in different materials, the heterojunction is very wide and its preparation is comparatively simple and the cost is not too high.

Although many approaches have been put forward, there is still much room for improvement. In terms of sensing gas, in my opinion, it is most important that materials must be stable in gas because of its performance or can be improved by some processes. Only in this way can it be practical and useful. At the same time, large surface-to-volume and not too difficult preparation and so on are also significant. More materials suitable for gas sensors should be excavated and through these enhancing approaches, can contribute a lot to gas nanosensors. Additionally, a more reasonable model for the gas sensing mechanism should also be connected to develop it better.

Author Contributions: Writing—review and editing, Z.Y.; funding acquisition, Z.Y. and F.M.; supervision, Z.Y. and F.M.; investigation, R.L.; resources, R.L.; writing—original draft preparation, R.L.; project administration, F.M.; validation, F.M.; conceptualization, J.Z.; formal analysis, K.Z.; methodology, E.H. Z.Y. and R.L. are co-first authors.

Funding: This work was funded by the National Natural Science Foundation of China $(61833006,61673367$ and 61504023), the Fundamental Research Funds for the Central Universities in China (N180408018, N170405001, N180102032 and N170407005), and the Liaoning Province Natural Science Foundation (20180550483 and 20170540324).

Conflicts of Interest: The authors declare no conflict of interest.

\section{References}

1. Li, Z.; Yao, Z.; Haidry, A.A.; Plecenik, T.; Xie, L.; Sun, L.; Fatima, Q. Resistive-type hydrogen gas sensor based on $\mathrm{TiO}_{2}$ : A review. Int. J. Hydrogen Energy 2018, 43, 21114-21132. [CrossRef]

2. Sertel, B.C.; Sonmez, N.A.; Kaya, M.D.; Ozcelik, S. Development of $\mathrm{MgO}: \mathrm{TiO}_{2}$ thin films for gas sensor applications. Ceram. Int. 2019, 45, 2917-2921. [CrossRef]

3. Meng, F.-L.; Zhang, L.; Jia, Y.; Liu, J.-Y.; Sun, Y.-F.; Luo, T.; Li, M.-Q.; Liu, J.-H.; Huang, X.-J. Electronic chip based on self-oriented carbon nanotube microelectrode array to enhance the sensitivity of indoor air pollutants capacitive detection. Sens. Actuators B Chem. 2011, 153, 103-109. [CrossRef]

4. Manjula, M.; Karthikeyan, B.; Sastikumar, D. Sensing characteristics of nanocrystalline bismuth oxide clad-modified fiber optic gas sensor. Opt. Lasers Eng. 2017, 95, 78-82. [CrossRef]

5. Wang, T.-Y.; Li, Y.-Y.; Li, T.-T.; Yu, H.; Yang, Y.; Yang, H.; Dong, X.-T. Enhanced NOx gas sensing properties of $\mathrm{Cr}_{2} \mathrm{O}_{3}$ film modified ordered porous $\mathrm{ZnO}$ gas sensors. Solid State Ionics 2018, 326, 173-182. [CrossRef]

6. Laborda, F.; Bolea, E. Nanomaterials Engineered Nanomaterials. In Encyclopedia of Analytical Science, 3rd ed.; Worsfold, P., Poole, C., Townshend, A., Miró, M., Eds.; Academic Press: Oxford, UK, 2018; pp. 108-116.

7. Heydari, M.; Ghoreishi, S.M.; Khoobi, A. Chemometrics-assisted determination of Sudan dyes using zinc oxide nanoparticle-based electrochemical sensor. Food Chem. 2019, 283, 68-72. [CrossRef] [PubMed] 
8. Kaur, H. Aptamer Conjugated Quantum Dots for Imaging Cellular Uptake in Cancer Cells. J. Nanosci. Nanotechnol. 2019, 19, 3798-3803. [CrossRef] [PubMed]

9. Yuan, Q.; Yao, Y.; Zhang, X.; Yuan, J.; Sun, B.; Gao, X. The Gold Nanocluster Protects Neurons Directly or via Inhibiting Cytotoxic Secretions of Microglia Cell. J. Nanosci. Nanotechnol. 2019, 19, 1986-1995. [CrossRef]

10. Kolmakov, A.; Zhang, Y.; Cheng, G.; Moskovits, M. Detection of $\mathrm{CO}$ and $\mathrm{O}_{2}$ Using Tin Oxide Nanowire Sensors. Adv. Mater. 2003, 15, 997-1000. [CrossRef]

11. Balaban, O.; Grygorchak, I.; Mitina, N.; Zaichenko, A.; Lukiyanets, B.; Glasunova, V.; Borysiuk, A.; Larkin, M.; Hevus, O.; Pokladok, N.; et al. Fabrication of 1D-Nanofiber $/ \mathrm{Fe}_{2} \mathrm{O}_{3}$ Composites with Tailored Magnetic Properties. J. Nanosci. Nanotechnol. 2019, 19, 3871-3878. [CrossRef] [PubMed]

12. Kumar, K.; Priya, A.; Arun, A.; Hait, S.; Chowdhury, A. Antibacterial and natural room-light driven photocatalytic activities of CuO nanorods. Mater. Chem. Phys. 2019, 226, 106-112. [CrossRef]

13. Liu, S.F.; Lin, S.; Swager, T.M. An Organocobalt-Carbon Nanotube Chemiresistive Carbon Monoxide Detector. ACS Sens. 2016, 1, 354-357. [CrossRef]

14. Choi, H.H.; Lee, J.; Dong, K.-Y.; Ju, B.-K.; Lee, W. Noxious gas detection using carbon nanotubes with Pd nanoparticles. Nanoscale Res. Lett. 2011, 6, 605. [CrossRef]

15. Wu, L.; Yang, D. Dielectric Properties and Thermal Conductivity of Poly(vinylidene fluoride)-Based Composites with Graphite Nanosheet and Nickel Particle. J. Nanosci. Nanotechnol. 2019, 19, 3591-3596. [CrossRef]

16. Qiao, Y.; Shi, C.; Wang, X.; Wang, P.; Zhang, Y.; Wang, D.; Qiao, R.; Wang, X.; Zhong, J. Electrospun Nanobelt-Shaped Polymer Membranes for Fast and High-Sensitivity Detection of Metal Ions. ACS Appl. Mater. Interfaces 2019, 11, 5401-5413. [CrossRef] [PubMed]

17. Sprouster, D.J.; Sun, C.; Zhang, Y.; Chodankar, S.N.; Gan, J.; Ecker, L.E. Irradiation-Dependent Helium Gas Bubble Superlattice in Tungsten. Sci. Rep. 2019, 9, 2277. [CrossRef] [PubMed]

18. Meng, D.; Liu, D.; Wang, G.; Shen, Y.; San, X.; Li, M.; Meng, F. Low-temperature formaldehyde gas sensors based on $\mathrm{NiO}-\mathrm{SnO}_{2}$ heterojunction microflowers assembled by thin porous nanosheets. Sens. Actuators $B$ Chem. 2018, 273, 418-428. [CrossRef]

19. Ma, S.S.; Li, R.; Lv, C.P.; Xu, W.; Gou, X.L. Facile synthesis of ZnO nanorod arrays and hierarchical nanostructures for photocatalysis and gas sensor applications. J. Hazard. Mater. 2011, 192, 730-740. [CrossRef] [PubMed]

20. Wei, Z.; Zhou, Q.; Lu, Z.; Xu, L.; Gui, Y.; Tang, C. Morphology Controllable Synthesis of Hierarchical $\mathrm{WO}_{3}$ Nanostructures and $\mathrm{C}_{2} \mathrm{H}_{2}$ Sensing Properties. Phys. E Low-Dimens. Syst. Nanostruct. 2019. [CrossRef]

21. Wu, D.; Li, C.; Kong, Q.; Shi, Z.; Zhang, D.; Wang, L.; Han, L.; Zhang, X.; Lin, Q. Photocatalytic activity of $\mathrm{Lu}^{3+} / \mathrm{TiO}_{2}$ prepared by ball milling method. J. Rare Earths 2018, 36, 819-825. [CrossRef]

22. Antisari, M.V.; Montone, A.; Jovic, N.; Piscopiello, E.; Alvani, C.; Pilloni, L. Low energy pure shear milling: A method for the preparation of graphite nano-sheets. Scr. Mater. 2006, 55, 1047-1050. [CrossRef]

23. Fireman, M.N.; L'Heureux, G.; Wu, F.; Mates, T.; Young, E.C.; Speck, J.S. High germanium doping of GaN films by ammonia molecular beam epitaxy. J. Cryst. Growth 2019, 508, 19-23. [CrossRef]

24. Sivajee Ganesh, K.; Purusottamreddy, B.; Jeevan Kumar, P.; Hussain, O.M. Influence of Zr dopant on microstructural and electrochemical properties of $\mathrm{LiCoO}_{2}$ thin film cathodes by RF sputtering. J. Electroanal. Chem. 2018, 828, 71-79. [CrossRef]

25. Hao, S.; Lin, T.; Ning, S.; Qi, Y.; Deng, Z.; Wang, Y. Research on cracking of $\mathrm{SiO}_{2}$ nanofilms prepared by the sol-gel method. Mater. Sci. Semicond. Process. 2019, 91, 181-187. [CrossRef]

26. Khan, J.; Ullah, H.; Sajjad, M.; Ali, A.; Thebo, K.H. Synthesis, characterization and electrochemical performance of cobalt fluoride nanoparticles by reverse micro-emulsion method. Inorg. Chem. Commun. 2018, 98, 132-140. [CrossRef]

27. Li, S.; Li, X.; Zou, K.; Huang, Z.; Zhang, L.; Zhou, X.; Guo, D.; Ju, Y. Preparation of single-crystalline BaTi ${ }_{5} \mathrm{O}_{11}$ nanocrystals by hydrothermal method. Mater. Lett. 2019. [CrossRef]

28. Keller, D.; Henninen, T.R.; Erni, R. Formation of gold nanoparticles in a free-standing ionic liquid triggered by heat and electron irradiation. Micron 2019, 117, 16-21. [CrossRef]

29. Lu, Z.; Wang, H.; Zeng, J.; Liu, J. Dynamic crystal-growth process observed during hydrothermal coarsening of nanocrystalline hydroxy fluorapatite. J. Cryst. Growth 2009, 311, 4791-4798. [CrossRef]

30. Kumar, V.; Kumar, P.; Pournara, A.; Vellingiri, K.; Kim, K.-H. Nanomaterials for the sensing of narcotics: Challenges and opportunities. TrAC Trends Anal. Chem. 2018, 106, 84-115. [CrossRef] 
31. Zou, S.; Luo, J.; Lin, Z.D.; Fu, P.; Chen, Z. Acetone gas sensor based on iron molybdate nanoparticles prepared by hydrothermal method with PVP as surfactant. Mater. Res. Express 2018, 5, 7. [CrossRef]

32. Ren, Y.; Yang, X.; Zhou, X.; Luo, W.; Zhang, Y.; Cheng, X.; Deng, Y. Amphiphilic block copolymers directed synthesis of mesoporous nickel-based oxides with bimodal mesopores and nanocrystal-assembled walls. Chin. Chem. Lett. 2019. [CrossRef]

33. An, S.; Park, S.; Ko, H.; Lee, C. Enhanced $\mathrm{NO}_{2}$ gas sensing properties of $\mathrm{WO}_{3}$ nanorods encapsulated with ZnO. Appl. Phys. A 2012, 108, 53-58. [CrossRef]

34. Patil, D.; Patil, P.; Subramanian, V.; Joy, P.A.; Potdar, H.S. Highly sensitive and fast responding CO sensor based on $\mathrm{Co}_{3} \mathrm{O}_{4}$ nanorods. Talanta 2010, 81, 37-43. [CrossRef] [PubMed]

35. Narayanan, G.N.; Annamalai, K. Development of Gas Sensor and Optical Properties of Zinc Oxide Nanorods by Simple Hydrothermal Approach. Mater. Today Proc. 2017, 4, 12070-12074. [CrossRef]

36. Narayanan, G.N.; Sankar Ganesh, R.; Karthigeyan, A. Effect of annealing temperature on structural, optical and electrical properties of hydrothermal assisted zinc oxide nanorods. Thin Solid Films 2016, 598, 39-45. [CrossRef]

37. Oh, E.; Choi, H.-Y.; Jung, S.-H.; Cho, S.; Kim, J.C.; Lee, K.-H.; Kang, S.-W.; Kim, J.; Yun, J.-Y.; Jeong, S.-H. High-performance $\mathrm{NO}_{2}$ gas sensor based on $\mathrm{ZnO}$ nanorod grown by ultrasonic irradiation. Sens. Actuators B Chem. 2009, 141, 239-243. [CrossRef]

38. Long, H.; Li, Y.; Zeng, W. Substrate-free synthesis of $\mathrm{WO}_{3}$ nanorod arrays and their superb $\mathrm{NH}_{3}$-sensing performance. Mater. Lett. 2017, 209, 342-344. [CrossRef]

39. Choi, P.G.; Izu, N.; Shirahata, N.; Masuda, Y. Fabrication and $\mathrm{H}_{2}$-Sensing Properties of $\mathrm{SnO}_{2}$ Nanosheet Gas Sensors. Acs Omega 2018, 3, 14592-14596. [CrossRef]

40. Li, Y.; Liu, B.; Wang, H.; Su, X.; Gao, L.; Zhou, F.; Duan, G. $\mathrm{Co}_{3} \mathrm{O}_{4}$ nanosheet-built hollow dodecahedrons via a two step self-templated method and their multifunctional applications. Sci. China Mater. 2018, 61, 1575-1586. [CrossRef]

41. Zhang, Y.-H.; Cai, X.-L.; Song, L.-Z.; Feng, F.-Y.; Ding, J.-Y.; Gong, F.-L. 2D nanosheet-assembled Pd-ZnOmicroflowers for acetone sensor with enhanced performances. J. Phys. Chem. Solids 2019, 124, 330-335. [CrossRef]

42. Wang, Y.Y.; Zhang, H.W.; Zhu, Y.D.; Dai, Z.F.; Bao, H.M.; Wei, Y.; Cai, W.P. Au-NP-Decorated Crystalline FeOCl Nanosheet: Facile Synthesis by Laser Ablation in Liquid and its Exclusive Gas Sensing Response to $\mathrm{HCl}$ at Room Temperature. Adv. Mater. Interfaces 2016, 3, 8. [CrossRef]

43. Pan, Y.; Liu, B.; Hu, H.; Jiang, H.; Wei, F.; Zhou, M.; Fan, X.; Yu, H.; Niu, G.; Huang, J. Preparation and photocatalytic performance of the rod-shaped $\mathrm{Ni}-\mathrm{NiO} / \mathrm{TiO}_{2}$ hollow composite structure based on metallization cellulose fibers and TBOT. Vacuum 2019, 159, 1-8. [CrossRef]

44. Xiao, Y.; Deng, Y.; Huan, W.; Li, J.; Zhang, J.; Xing, M. Hollow-structured $\mathrm{Fe}_{2} \mathrm{O}_{3} / \mathrm{Au} / \mathrm{SiO}_{2}$ nanorods with enhanced and recyclable photo-Fenton oxidation for the remediation of organic pollutants. Mater. Today Chem. 2019, 11, 86-93. [CrossRef]

45. An, G.S.; Chae, D.H.; Hur, J.U.; Oh, A.H.; Choi, H.-H.; Choi, S.-C.; Oh, Y.-S.; Jung, Y.-G. Hollow-structured $\mathrm{Fe}_{3} \mathrm{O}_{4} @ \mathrm{SiO}_{2}$ nanoparticles: Novel synthesis and enhanced adsorbents for purification of plasmid DNA. Ceram. Int. 2018, 44, 18791-18795. [CrossRef]

46. Kang, Y.; Li, Z.; Xu, K.; He, X.; Wei, S.; Cao, Y. Hollow $\mathrm{SnO}_{2}$ nanospheres with single-shelled structure and the application for supercapacitors. J. Alloys Compd. 2019, 779, 728-734. [CrossRef]

47. Lai, X.; Halpert, J.E.; Wang, D. Recent advances in micro-/nano-structured hollow spheres for energy applications: From simple to complex systems. Energy Environ. Sci. 2012, 5, 5604-5618. [CrossRef]

48. Xie, F.; Qi, M.Z.; Li, W.J.; Wang, K.; Yu, Z.Y.; Liu, B. Classification, Fabrication Methods and Applications of Inorganic Hollow Spheres. Progress Chem. 2011, 23, 2522-2533.

49. Han, D.; Song, P.; Zhang, H.; Yang, Z.; Wang, Q. $\mathrm{Cu}_{2} \mathrm{O}$ template-assisted synthesis of porous $\mathrm{In}_{2} \mathrm{O}_{3}$ hollow spheres with fast response towards acetone. Mater. Lett. 2014, 124, 93-96. [CrossRef]

50. Zhai, C.; Zhu, M.; Jiang, L.; Yang, T.; Zhao, Q.; Luo, Y.; Zhang, M. Fast triethylamine gas sensing response properties of nanosheets assembled $\mathrm{WO}_{3}$ hollow microspheres. App. Surf. Sci. 2019, 463, 1078-1084. [CrossRef]

51. Wang, L.; Wang, S.; Wang, Y.; Zhang, H.; Kang, Y.; Huang, W. Synthesis of hierarchical $\mathrm{SnO}_{2}$ nanostructures assembled with nanosheets and their improved gas sensing properties. Sens. Actuators B Chem. 2013, 188, 85-93. [CrossRef] 
52. Song, Y.; Chen, F.; Zhang, Y.; Zhang, S.; Liu, F.; Sun, P.; Yan, X.; Lu, G. Fabrication of highly sensitive and selective room-temperature nitrogen dioxide sensors based on the $\mathrm{ZnO}$ nanoflowers. Sens. Actuators B Chem. 2019, 287, 191-198. [CrossRef]

53. Zhu, L.; Zeng, W.; Li, Y. A non-oxygen adsorption mechanism for hydrogen detection of nanostructured $\mathrm{SnO}_{2}$ based sensors. Mater. Res. Bull. 2019, 109, 108-116. [CrossRef]

54. Guan, C.; Xia, X.; Meng, N.; Zeng, Z.; Cao, X.; Soci, C.; Zhang, H.; Fan, H.J. Hollow core-shell nanostructure supercapacitor electrodes: Gap matters. Energy Environ. Sci. 2012, 5, 9085-9090. [CrossRef]

55. Ma, Z.; Shao, G.; Fan, Y.; Wang, G.; Song, J.; Shen, D. Construction of Hierarchical alpha-MnO $\mathrm{M}_{2}$ Nanowires@Ultrathin delta- $\mathrm{MnO}_{2}$ Nanosheets Core-Shell Nanostructure with Excellent Cycling Stability for High-Power Asymmetric Supercapacitor Electrodes. ACS Appl. Mater. Interfaces 2016, 8, 9050-9058. [CrossRef]

56. Santra, S.; Liesenfeld, B.; Bertolino, C.; Dutta, D.; Cao, Z.H.; Tan, W.H.; Moudgil, B.M.; Mericle, R.A. Fluorescence lifetime measurements to determine the core-shell nanostructure of FITC-doped silica nanoparticles: An optical approach to evaluate nanoparticle photostability. J. Lumin. 2006, 117, 75-82. [CrossRef]

57. Kong, J.; Liu, Z.; Yang, Z.; Tan, H.R.; Xiong, S.; Wong, S.Y.; Li, X.; Lu, X. Carbon $/ \mathrm{SnO}_{2} / \mathrm{carbon}$ core/shell/shell hybrid nanofibers: Tailored nanostructure for the anode of lithium ion batteries with high reversibility and rate capacity. Nanoscale 2012, 4, 525-530. [CrossRef] [PubMed]

58. Liu, S.; Feng, J.; Bian, X.; Liu, J.; Xu, H.; An, Y. A controlled red phosphorus@Ni-Pcore@shell nanostructure as an ultralong cycle-life and superior high-rate anode for sodium-ion batteries. Energy Environ. Sci. 2017, 10, 1222-1233. [CrossRef]

59. Misra, M.; Kapur, P.; Singla, M.L. Surface plasmon quenched of near band edge emission and enhanced visible photocatalytic activity of Au@ZnO core-shell nanostructure. Appl. Catal. B Environ. 2014, 150, 605-611. [CrossRef]

60. Senapati, S.; Srivastava, S.K.; Singh, S.B.; Mishra, H.N. Magnetic Ni/Ag core-shell nanostructure from prickly Ni nanowire precursor and its catalytic and antibacterial activity. J. Mater. Chem. 2012, 22, 6899-6906. [CrossRef]

61. Veisi, H.; Taheri, S.; Hemmati, S. Preparation of polydopamine sulfamic acid-functionalized magnetic $\mathrm{Fe}_{3} \mathrm{O}_{4}$ nanoparticles with a core/shell nanostructure as heterogeneous and recyclable nanocatalysts for the acetylation of alcohols, phenols, amines and thiols under solvent-free conditions. Green Chem. 2016, 18, 6337-6348. [CrossRef]

62. Xu, M.; Chen, D.; Huang, P.; Wan, Z.; Zhou, Y.; Ji, Z. A dual-functional upconversion core@shell nanostructure for white-light-emission and temperature sensing. J. Mater. Chem. C 2016, 4, 6516-6524. [CrossRef]

63. Yu, Y.-T.; Majhi, S.M.; Song, H.-G. Synthesis and Gas Sensing Properties of $\mathrm{Au} @ \mathrm{In}_{2} \mathrm{O}_{3}$ Core-shell Nanoparticles. Procedia Eng. 2016, 168, 227-230. [CrossRef]

64. Jin, C.; Park, S.; Kim, H.; Lee, C. Ultrasensitive multiple networked $\mathrm{Ga}_{2} \mathrm{O}_{3}$-core/ZnO-shell nanorod gas sensors. Sens. Actuators B Chem. 2012, 161, 223-228. [CrossRef]

65. Si, S.; Li, C.; Wang, X.; Peng, Q.; Li, Y. $\mathrm{Fe}_{2} \mathrm{O}_{3} / \mathrm{ZnO}$ core-shell nanorods for gas sensors. Sens. Actuators $B$ Chem. 2006, 119, 52-56. [CrossRef]

66. Li, F.; Zhang, T.; Gao, X.; Wang, R.; Li, B. Coaxial electrospinning heterojunction $\mathrm{SnO}_{2} / \mathrm{Au}$-doped $\mathrm{In}_{2} \mathrm{O}_{3}$ core-shell nanofibers for acetone gas sensor. Sens. Actuators B Chem. 2017, 252, 822-830. [CrossRef]

67. Park, S.; Ko, H.; Lee, S.; Kim, H.; Lee, C. Light-activated gas sensing of $\mathrm{Bi}_{2} \mathrm{O}_{3}$-core/ZnO-shell nanobelt gas sensors. Thin Solid Films 2014, 570, 298-302. [CrossRef]

68. Thanh Le, D.T.; Trung, D.D.; Chinh, N.D.; Thanh Binh, B.T.; Hong, H.S.; Van Duy, N.; Hoa, N.D.; Van Hieu, N. Facile synthesis of $\mathrm{SnO}_{2}-\mathrm{ZnO}$ core-shell nanowires for enhanced ethanol-sensing performance. Curr. Appl. Phys. 2013, 13, 1637-1642. [CrossRef]

69. Xu, H.; Li, W.; Han, R.; Zhai, T.; Yu, H.; Chen, Z.; Wu, X.; Wang, J.; Cao, B. Enhanced triethylamine sensing properties by fabricating $\mathrm{Au} @ \mathrm{SnO}_{2} / \alpha-\mathrm{Fe}_{2} \mathrm{O}_{3}$ core-shell nanoneedles directly on alumina tubes. Sens. Actuators B Chem. 2018, 262, 70-78. [CrossRef]

70. Wang, Y.; Qu, F.; Liu, J.; Wang, Y.; Zhou, J.; Ruan, S. Enhanced $\mathrm{H}_{2} \mathrm{~S}$ sensing characteristics of $\mathrm{CuO}-\mathrm{NiO}$ core-shell microspheres sensors. Sens. Actuators B Chem. 2015, 209, 515-523. [CrossRef]

71. Yao, Y.; Yin, M.; Yan, J.; Yang, D.; Liu, S. Controllable synthesis of Ag- $\mathrm{WO}_{3}$ core-shell nanospheres for light-enhanced gas sensors. Sens. Actuators B Chem. 2017, 251, 583-589. [CrossRef] 
72. Yu, Q.; Zhu, J.; Xu, Z.; Huang, X. Facile synthesis of $\alpha-\mathrm{Fe}_{2} \mathrm{O}_{3} @ \mathrm{SnO}_{2}$ core-shell heterostructure nanotubes for high performance gas sensors. Sens. Actuators B Chem. 2015, 213, 27-34. [CrossRef]

73. Zhu, Z.; Kao, C.-T.; Wu, R.-J. A highly sensitive ethanol sensor based on $\mathrm{Ag@} \mathrm{TiO}_{2}$ nanoparticles at room temperature. Appl. Surf. Sci. 2014, 320, 348-355. [CrossRef]

74. Li, C.; Su, Y.; Lv, X.; Zuo, Y.; Yang, X.; Wang, Y. Au@Pd core-shell nanoparticles: A highly active electrocatalyst for amperometric gaseous ethanol sensors. Sens. Actuators B Chem. 2012, 171-172, 1192-1198. [CrossRef]

75. Guo, L.; Yang, Z.; Li, Y.; Zu, B.; Dou, X. Sensitive, real-time and anti-interfering detection of nitro-explosive vapors realized by ZnO/rGO core/shell micro-Schottky junction. Sens. Actuators B Chem. 2017, 239, $286-294$. [CrossRef]

76. Li, S.; Diao, Y.; Yang, Z.; He, J.; Wang, J.; Liu, C.; Liu, F.; Lu, H.; Yan, X.; Sun, P.; et al. Enhanced room temperature gas sensor based on Au-loaded mesoporous $\operatorname{In}_{2} \mathrm{O}_{3}$ nanospheres@polyaniline core-shell nanohybrid assembled on flexible PET substrate for NH3 detection. Sens. Actuators B Chem. 2018, 276, 526-533. [CrossRef]

77. Saboor, F.H.; Khodadadi, A.A.; Mortazavi, Y.; Asgari, M. Microemulsion synthesized silica/ZnO stable core/shell sensors highly selective to ethanol with minimum sensitivity to humidity. Sens. Actuators B Chem. 2017, 238, 1070-1083. [CrossRef]

78. Park, S.; Kim, S.; Sun, G.-J.; Lee, C. Synthesis, structure and ethanol sensing properties of $\mathrm{Ga}_{2} \mathrm{O}_{3}$-core $/ \mathrm{WO}_{3}$-shell nanostructures. Thin Solid Films 2015, 591, 341-345. [CrossRef]

79. Runa, A.; Zhang, X.; Wen, G.; Zhang, B.; Fu, W.; Yang, H. Actinomorphic flower-like n-ZnO/p-ZnFe $2 \mathrm{O}_{4}$ composite and its improved $\mathrm{NO}_{2}$ gas-sensing property. Mater. Lett. 2018, 225, 73-76. [CrossRef]

80. Uddin, A.S.M.I.; Yaqoob, U.; Hassan, K.; Chung, G.-S. Effects of Pt shell thickness on self-assembly monolayer Pd@Pt core-shell nanocrystals based hydrogen sensing. Int. J. Hydrogen Energy 2016, 41, 15399-15410. [CrossRef]

81. Gangu, K.K.; Maddila, S.; Mukkamala, S.B.; Jonnalagadda, S.B. Characteristics of MOF, MWCNT and graphene containing materials for hydrogen storage: A review. J. Energy Chem. 2019, 30, 132-144. [CrossRef]

82. Pumera, M. Electrochemistry of graphene, graphene oxide and other graphenoids: Review. Electrochem. Commun. 2013, 36, 14-18. [CrossRef]

83. Ren, S.; Rong, P.; Yu, Q. Preparations, properties and applications of graphene in functional devices: A concise review. Ceram. Int. 2018, 44, 11940-11955. [CrossRef]

84. Al Hassan, M.R.; Sen, A.; Zaman, T.; Mostari, M.S. Emergence of graphene as a promising anode material for rechargeable batteries: A review. Mater. Today Chem. 2019, 11, 225-243. [CrossRef]

85. Vasut, F.; Oubraham, A.; Soare, A.M.; Marinoiu, A.; Ion-Ebrasu, D.; Dragan, M. Platinum supported on graphene-PTFE as catalysts for isotopic exchange in a detritiation plant. Fusion Eng. Des. 2018. [CrossRef]

86. Nikbakht, H.; Latifi, H.; Pak, M.; Behroodi, E.; Oraie, M.; Zibaii, M.I. Sensitivity enhancement of cylindrically-symmetric optical fiber refractive index sensors by utilizing graphene. Opt. Commun. 2018, 429, 1-4. [CrossRef]

87. Justh, N.; Berke, B.; Laszlo, K.; Bakos, L.P.; Szabo, A.; Hernadi, K.; Szilagyi, I.M. Preparation of graphene oxide/semiconductor oxide composites by using atomic layer deposition. Appl. Surf. Sci. 2018, 453, $245-251$. [CrossRef]

88. Wu, C.-H.; Pu, N.-W.; Liu, Y.-M.; Chen, C.-Y.; Peng, Y.-Y.; Cheng, T.-Y.; Lin, M.-H.; Ger, M.-D. Improving rate capability of lithium-ion batteries using holey graphene as the anode material. J. Taiwan Inst. Chem. Eng. 2017, 80, 511-517. [CrossRef]

89. Bera, S.; Kundu, S.; Khan, H.; Jana, S. Polyaniline coated graphene hybridized $\mathrm{SnO}_{2}$ nanocomposite: Low temperature solution synthesis, structural property and room temperature ammonia gas sensing. J. Alloys Compd. 2018, 744, 260-270. [CrossRef]

90. Liu, J.; Li, S.; Zhang, B.; Wang, Y.; Gao, Y.; Liang, X.; Wang, Y.; Lu, G. Flower-like $\mathrm{In}_{2} \mathrm{O}_{3}$ modified by reduced graphene oxide sheets serving as a highly sensitive gas sensor for trace $\mathrm{NO}_{2}$ detection. J. Colloid Interface Sci. 2017, 504, 206-213. [CrossRef]

91. Zhang, J.; Wu, J.; Wang, X.; Zeng, D.; Xie, C. Enhancing room-temperature $\mathrm{NO}_{2}$ sensing properties via forming heterojunction for NiO-rGO composited with $\mathrm{SnO}_{2}$ nanoplates. Sens. Actuators B Chem. 2017, 243, 1010-1019. [CrossRef] 
92. Li, Y.; Luo, N.; Sun, G.; Zhang, B.; Lin, L.; Jin, H.; Wang, Y.; Bala, H.; Cao, J.; Zhang, Z. In situ decoration of $\mathrm{Zn}_{2} \mathrm{SnO}_{4}$ nanoparticles on reduced graphene oxide for high performance ethanol sensor. Ceram. Int. 2018, 44, 6836-6842. [CrossRef]

93. Furlan, K.P.; de Mello, J.D.B.; Klein, A.N. Self-lubricating composites containing $\mathrm{MoS}_{2}$ : A review. Tribol. Int. 2018, 120, 280-298. [CrossRef]

94. Krishnan, U.; Kaur, M.; Singh, K.; Kumar, M.; Kumar, A. A synoptic review of $\mathrm{MoS}_{2}$ : Synthesis to applications. Superlattices Microstruct. 2019, 128, 274-297. [CrossRef]

95. Sinha, A.; Dhanjai; Tan, B.; Huang, Y.; Zhao, H.; Dang, X.; Chen, J.; Jain, R. MoS 2 nanostructures for electrochemical sensing of multidisciplinary targets: A review. TrAC Trends Anal. Chem. 2018, 102, 75-90. [CrossRef]

96. Jinxiao, W.; Jianfeng, Y.; Jun, Y.; Guanjun, Q.; Hang, W.; WangRui, H. Superior MoS $_{2}$-decorated CNT composite materials for photoelectric detectors. Opt. Mater. 2018, 86, 113-118. [CrossRef]

97. Kathiravan, D.; Huang, B.-R.; Saravanan, A.; Prasannan, A.; Hong, P.-D. Highly enhanced hydrogen sensing properties of sericin-induced exfoliated $\mathrm{MoS}_{2}$ nanosheets at room temperature. Sens. Actuators B Chem. 2019, 279, 138-147. [CrossRef]

98. Benavente, E.; Durán, F.; Sotomayor-Torres, C.; González, G. Heterostructured layered hybrid ZnO/MoS nanosheets with enhanced visible light photocatalytic activity. J. Phys. Chem. Solids 2018, 113, 119-124. [CrossRef]

99. Luxa, J.; Mazánek, V.; Mackova, A.; Malinsky, P.; Akhmadaliev, S.; Sofer, Z. Tuning of electrocatalytic properties of $\mathrm{MoS}_{2}$ by chalcogenide ion implantation. Appl. Mater. Today 2019, 14, 216-223. [CrossRef]

100. Jia, Y.; Lin, Y.; Ma, Y.; Shi, W. Hierarchical $\mathrm{MnS}_{2}-\mathrm{MoS}_{2}$ nanotubes with efficient electrochemical performance for energy storage. Mater. Des. 2018, 160, 1071-1079. [CrossRef]

101. Charoo, M.S.; Wani, M.F.; Hanief, M.; Rather, M.A. Tribological Properties of $\mathrm{MoS}_{2}$ Particles as Lubricant Additive on EN31 Alloy Steel and AISI 52100 Steel Ball. Mater. Today Proc. 2017, 4, 9967-9971. [CrossRef]

102. Luo, Y.; Zhang, C. Pt-activated $\mathrm{TiO}_{2}-\mathrm{MoS}_{2}$ nanocomposites for $\mathrm{H} 2$ detection at low temperature. J. Alloys Compd. 2018, 747, 550-557. [CrossRef]

103. Baek, D.-H.; Kim, J. MoS 2 gas sensor functionalized by Pd for the detection of hydrogen. Sens. Actuators $B$ Chem. 2017, 250, 686-691. [CrossRef]

104. Yoo, S.; Kim, S.; Song, Y.-W. Lithography-free fabrication of field effect transistor channels with randomly contact-printed black phosphorus flakes. Mater. Sci. Semicond. Process. 2018, 86, 58-62. [CrossRef]

105. Zhang, R.; Chen, W. Recent advances in graphene-based nanomaterials for fabricating electrochemical hydrogen peroxide sensors. Biosens. Bioelectron. 2017, 89, 249-268. [CrossRef]

106. Yi, Y.; Yu, X.-F.; Zhou, W.; Wang, J.; Chu, P.K. Two-dimensional black phosphorus: Synthesis, modification, properties, and applications. Mater. Sci. Eng. R Rep. 2017, 120, 1-33. [CrossRef]

107. Yang, A.J.; Wang, D.W.; Wang, X.H.; Zhang, D.Z.; Koratkar, N.; Rong, M.Z. Recent advances in phosphorene as a sensing material. Nano Today 2018, 20, 13-32. [CrossRef]

108. Anju, S.; Ashtami, J.; Mohanan, P.V. Black phosphorus, a prospective graphene substitute for biomedical applications. Mater. Sci. Eng. C 2019. [CrossRef] [PubMed]

109. Lee, B.C.; Kim, C.M.; Jang, H.K.; Lee, J.W.; Joo, M.-K.; Kim, G.-T. Degradation pattern of black phosphorus multilayer field-effect transistors in ambient conditions: Strategy for contact resistance engineering in BP transistors. Appl. Surf. Sci. 2017, 419, 637-641. [CrossRef]

110. Seo, S.; Park, B.; Kim, Y.; Lee, H.U.; Kim, H.; Lee, S.Y.; Kim, Y.; Won, J.; Kim, Y.J.; Lee, J. Black phosphorus quantum dot-based field-effect transistors with ambipolar characteristics. App. Surf. Sci. 2018, 448, 576-582. [CrossRef]

111. Zhou, G.; Pu, H.; Chang, J.; Sui, X.; Mao, S.; Chen, J. Real-time electronic sensor based on black phosphorus/Au NPs/DTT hybrid structure: Application in arsenic detection. Sens. Actuators B Chem. 2018, 257, 214-219. [CrossRef]

112. Guo, Z.; Ding, W.; Liu, X.; Sun, Z.; Wei, L. Two-dimensional black phosphorus: A new star in energy applications and the barrier to stability. Appl. Mater. Today 2019, 14, 51-58. [CrossRef]

113. Lin, S.; Li, Y.; Qian, J.; Lau, S.P. Emerging opportunities for black phosphorus in energy applications. Mater. Today Energy 2019, 12, 1-25. [CrossRef]

114. Xu, J.; Song, Y.J.; Park, J.H.; Lee, S. Graphene/black phosphorus heterostructured photodetector. Solid-State Electron. 2018, 144, 86-89. [CrossRef] 
115. Lee, G.; Kim, S.; Jung, S.; Jang, S.; Kim, J. Suspended black phosphorus nanosheet gas sensors. Sens. Actuators B Chem. 2017, 250, 569-573. [CrossRef]

116. Hu, Z.; Li, Y.; Hussain, E.; Huang, X.; Zhang, Y.; Niu, N.; Shahzad, S.A.; Yu, C. Black phosphorus nanosheets based sensitive protease detection and inhibitor screening. Talanta 2019, 197, 270-276. [CrossRef]

117. Han, Z.; Wang, J.; Liao, L.; Pan, H.; Shen, S.; Chen, J. Phosphorus doped $\mathrm{TiO}_{2}$ as oxygen sensor with low operating temperature and sensing mechanism. Appl. Surf. Sci. 2013, 273, 349-356. [CrossRef]

118. Meng, F.; Zheng, H.; Sun, Y.; Li, M.; Liu, J. Trimethylamine Sensors Based on Au-Modified Hierarchical Porous Single-Crystalline ZnO Nanosheets. Sensors 2017, 17, 1478. [CrossRef] [PubMed]

119. Yuan, Z.; Zhang, J.; Meng, F.; Li, Y.; Li, R.; Chang, Y.; Zhao, J.; Han, E.; Wang, S. Highly Sensitive Ammonia Sensors Based on Ag-Decorated $\mathrm{WO}_{3}$ Nanorods. IEEE Trans. Nanotechnol. 2018, 17, 1252-1258. [CrossRef]

120. Deng, X.; Zhang, L.; Guo, J.; Chen, Q.; Ma, J. ZnO enhanced NiO-based gas sensors towards ethanol. Mater. Res. Bull. 2017, 90, 170-174. [CrossRef]

121. Wang, P.; Dong, T.; Jia, C.; Yang, P. Ultraselective acetone-gas sensor based ZnO flowers functionalized by Au nanoparticle loading on certain facet. Sens. Actuators B Chem. 2019, 288, 1-11. [CrossRef]

122. Zhang, Y.; Liu, Y.; Zhou, L.; Liu, D.; Liu, F.; Liu, F.; Liang, X.; Yan, X.; Gao, Y.; Lu, G. The role of Ce doping in enhancing sensing performance of $\mathrm{ZnO}$-based gas sensor by adjusting the proportion of oxygen species. Sens. Actuators B Chem. 2018, 273, 991-998. [CrossRef]

123. Arunkumar, S.; Hou, T.; Kim, Y.-B.; Choi, B.; Park, S.H.; Jung, S.; Lee, D.-W. Au Decorated ZnO hierarchical architectures: Facile synthesis, tunable morphology and enhanced $\mathrm{CO}$ detection at room temperature. Sens. Actuators B Chem. 2017, 243, 990-1001. [CrossRef]

124. Lin, L.; Liu, T.; Zhang, Y.; Liang, X.; Sun, R.; Zeng, W.; Wang, Z. Enhancing ethanol detection by heterostructural silver nanoparticles decorated polycrystalline zinc oxide nanosheets. Ceram. Int. 2016, 42, 3138-3144. [CrossRef]

125. Liu, X.; Sun, Y.; Yu, M.; Yin, Y.; Du, B.; Tang, W.; Jiang, T.; Yang, B.; Cao, W.; Ashfold, M.N.R. Enhanced ethanol sensing properties of ultrathin $\mathrm{ZnO}$ nanosheets decorated with $\mathrm{CuO}$ nanoparticles. Sens. Actuators B Chem. 2018, 255, 3384-3390. [CrossRef]

126. Barbosa, M.S.; Suman, P.H.; Kim, J.J.; Tuller, H.L.; Varela, J.A.; Orlandi, M.O. Gas sensor properties of Agand Pd-decorated $\mathrm{SnO}$ micro-disks to $\mathrm{NO}_{2}, \mathrm{H}_{2}$ and $\mathrm{CO}$ : Catalyst enhanced sensor response and selectivity. Sens. Actuators B Chem. 2017, 239, 253-261. [CrossRef]

127. Nakate, U.T.; Bulakhe, R.N.; Lokhande, C.D.; Kale, S.N. Au sensitized ZnO nanorods for enhanced liquefied petroleum gas sensing properties. Appl. Surf. Sci. 2016, 371, 224-230. [CrossRef]

128. Kim, J.-H.; Mirzaei, A.; Kim, H.W.; Kim, S.S. Improving the hydrogen sensing properties of $\mathrm{SnO}_{2}$ nanowire-based conductometric sensors by Pd-decoration. Sens. Actuators B Chem. 2019, 285, 358-367. [CrossRef]

129. Wang, Y.; Zhang, B.; Liu, J.; Yang, Q.; Cui, X.; Gao, Y.; Chuai, X.; Liu, F.; Sun, P.; Liang, X.; et al. Au-loaded mesoporous $\mathrm{WO}_{3}$ : Preparation and n-butanol sensing performances. Sens. Actuators B Chem. 2016, 236, 67-76. [CrossRef]

130. Zhang, S.; Song, P.; Zhang, J.; Yan, H.; Li, J.; Yang, Z.; Wang, Q. Highly sensitive detection of acetone using mesoporous $\mathrm{In}_{2} \mathrm{O}_{3}$ nanospheres decorated with Au nanoparticles. Sens. Actuators B Chem. 2017, 242, 983-993. [CrossRef]

131. Choi, M.S.; Bang, J.H.; Mirzaei, A.; Oum, W.; Na, H.G.; Jin, C.; Kim, S.S.; Kim, H.W. Promotional effects of $\mathrm{ZnO}$-branching and Au-functionalization on the surface of $\mathrm{SnO}_{2}$ nanowires for $\mathrm{NO}_{2}$ sensing. J. Alloys Compd. 2019, 786, 27-39. [CrossRef]

132. Esfandiar, A.; Ghasemi, S.; Irajizad, A.; Akhavan, O.; Gholami, M.R. The decoration of $\mathrm{TiO}_{2} / \mathrm{reduced}$ graphene oxide by Pd and Pt nanoparticles for hydrogen gas sensing. Int. J. Hydrogen Energy 2012, 3, 15423-15432. [CrossRef]

133. Fan, F.Y.; Zhang, J.J.; Li, J.; Zhang, N.; Hong, R.R.; Deng, X.C.; Tang, P.G.; Li, D.Q. Hydrogen sensing properties of Pt-Au bimetallic nanoparticles loaded on ZnO nanorods. Sens. Actuators B Chem. 2017, 241, 895-903. [CrossRef]

134. Ma, R.J.; Li, G.D.; Zou, X.X.; Gao, R.Q.; Chen, H.; Zhao, X. Bimetallic Pt-Au nanocatalysts decorated $\mathrm{In}_{2} \mathrm{O}_{3}$ nests composed of ultrathin nanosheets for Type 1 diabetes diagnosis. Sens. Actuators B Chem. 2018, 270, 247-255. [CrossRef] 
135. Pajooheshpour, N.; Rezaei, M.; Hajian, A.; Afkhami, A.; Sillanpaa, M.; Arduini, F.; Bagheri, H. Protein templated Au-Pt nanoclusters-graphene nanoribbons as a high performance sensing layer for the electrochemical determination of diazinon. Sens. Actuators B Chem. 2018, 275, 180-189. [CrossRef]

136. Hassan, K.; Chung, G.S. Catalytically activated quantum-size Pt/Pd bimetallic core-shell nanoparticles decorated on $\mathrm{ZnO}$ nanorod clusters for accelerated hydrogen gas detection. Sens. Actuators B Chem. 2017, 239, 824-833. [CrossRef]

137. Kutukov, P.; Rumyantseva, M.; Krivetskiy, V.; Filatova, D.; Batuk, M.; Hadermann, J.; Khmelevsky, N.; Aksenenko, A.; Gaskov, A. Influence of Mono- and Bimetallic PtOx, PdOx, PtPdOx Clusters on CO Sensing by $\mathrm{SnO}_{2}$ Based Gas Sensors. Nanomaterials 2018, 8, 917. [CrossRef] [PubMed]

138. Malkov, I.V.; Krivetskii, V.V.; Potemkin, D.I.; Zadesenets, A.V.; Batuk, M.M.; Hadermann, J.; Marikutsa, A.V.; Rumyantseva, M.N.; Gas'kov, A.M. Effect of Bimetallic Pd/Pt Clusters on the Sensing Properties of Nanocrystalline $\mathrm{SnO}_{2}$ in the Detection of CO. Russ. J. Inorg. Chem. 2018, 63, 1007-1011. [CrossRef]

139. Nie, Q.; Zhang, W.; Wang, L.R.; Guo, Z.; Li, C.Y.; Yao, J.; Li, M.; Wu, D.M.; Zhou, L.Q. Sensitivity enhanced, stability improved ethanol gas sensor based on multi-wall carbon nanotubes functionalized with Pt-Pd nanoparticles. Sens. Actuators B Chem. 2018, 270, 140-148. [CrossRef]

140. Rahaman, M.H.; Hassan, K.; Chung, G.-S.; Kim, H.C. Catalytic Behaviors of Pt/Pd Bimetallic Core-shell Nanoparticles Decorated on Different Basal Podium for Fast Response Hydrogen Sensing. IEEE Sens. 2017, 1323-1325. [CrossRef]

141. Majumdar, S.; Nandi, A.; Saha, H. Synergistic Effects of Dual-Metal Catalysts for Selective Butane Detection by $\mathrm{SnO}_{2} /$ Graphene Nanocomposite Sensor. IEEE Sens. J. 2018, 18, 6517-6526. [CrossRef]

142. Ng, K.C.; Lin, F.C.; Yang, P.W.; Chuang, Y.C.; Chang, C.K.; Yeh, A.H.; Kuo, C.S.; Kao, C.R.; Liu, C.C.; Jeng, U.S.; et al. Fabrication of Bimetallic Au-Pd-Au Nanobricks as an Archetype of Robust Nanoplasmonic Sensors. Chem. Mater. 2018, 30, 204-213. [CrossRef]

143. Misra, M.; Singh, N.; Gupta, R.K. Enhanced visible-light-driven photocatalytic activity of Au@Ag core-shell bimetallic nanoparticles immobilized on electrospun $\mathrm{TiO}_{2}$ nanofibers for degradation of organic compounds. Catal. Sci. Technol. 2017, 7, 570-580. [CrossRef]

144. Kim, S.; Park, S.; Park, S.; Lee, C. Acetone sensing of $\mathrm{Au}$ and Pd-decorated $\mathrm{WO}_{3}$ nanorod sensors. Sens. Actuators B Chem. 2015, 209, 180-185. [CrossRef]

145. Motaung, D.E.; Mhlongo, G.H.; Makgwane, P.R.; Dhonge, B.P.; Cummings, F.R.; Swart, H.C.; Ray, S.S. Ultra-high sensitive and selective $\mathrm{H}_{2}$ gas sensor manifested by interface of $n-n$ heterostructure of $\mathrm{CeO}_{2}-\mathrm{SnO}_{2}$ nanoparticles. Sens. Actuators B Chem. 2018, 254, 984-995. [CrossRef]

146. Xu, H.; Ju, J.; Li, W.; Zhang, J.; Wang, J.; Cao, B. Superior triethylamine-sensing properties based on $\mathrm{TiO}_{2} / \mathrm{SnO}_{2}$ n-n heterojunction nanosheets directly grown on ceramic tubes. Sens. Actuators B Chem. 2016, 228, 634-642. [CrossRef]

147. Wang, T.; Kou, X.; Zhao, L.; Sun, P.; Liu, C.; Wang, Y.; Shimanoe, K.; Yarnazoe, N.; Lu, G. Flower-like ZnO hollow microspheres loaded with $\mathrm{CdO}$ nanoparticles as high performance sensing material for gas sensors. Sens. Actuators B Chem. 2017, 250, 692-702. [CrossRef]

148. Li, W.; Ma, S.; Li, Y.; Yang, G.; Mao, Y.; Luo, J.; Gengzang, D.; Xu, X.; Yan, S. Enhanced ethanol sensing

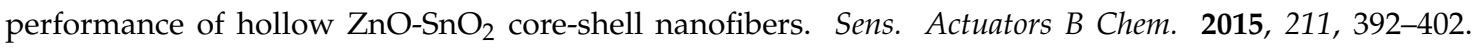
[CrossRef]

149. Ju, D.-X.; Xu, H.-Y.; Qiu, Z.-W.; Zhang, Z.-C.; Xu, O.; Zhang, J.; Wang, J.-Q.; Cao, B.-Q. Near Room Temperature, Fast-Response, and Highly Sensitive Triethylamine Sensor Assembled with Au-Loaded $\mathrm{ZnO} / \mathrm{SnO}_{2}$ Core Shell Nanorods on Flat Alumina Substrates. ACS Appl. Mater. Interfaces 2015, 7, 19163-19171. [CrossRef]

150. Tang, W.; Wang, J. Methanol sensing micro-gas sensors of $\mathrm{SnO}_{2}-\mathrm{ZnO}$ nanofibers on $\mathrm{Si} / \mathrm{SiO} 2 / \mathrm{Ti} / \mathrm{Pt}$ substrate via stepwise-heating electrospinning. J. Mater. Sci. 2015, 50, 4209-4220. [CrossRef]

151. Wu, Q.; Yang, H.; Zhu, H.; Gao, Z. Construction of $\mathrm{CNCs}^{-\mathrm{TiO}_{2}}$ heterojunctions with enhanced photocatalytic activity for crystal violet removal. Optik 2019, 179, 195-206. [CrossRef]

152. Wu, X.; Ng, Y.H.; Wen, X.; Chung, H.Y.; Wong, R.J.; Du, Y.; Dou, S.X.; Amal, R.; Scott, J. Construction of a $\mathrm{Bi}_{2} \mathrm{MoO}_{6}: \mathrm{Bi}_{2} \mathrm{Mo}_{3} \mathrm{O}_{12}$ heterojunction for efficient photocatalytic oxygen evolution. Chem. Eng. J. 2018, 353, 636-644. [CrossRef] 
153. Chen, X.; Zhang, J.; Zeng, J.; Shi, Y.; Lin, S.; Huang, G.; Wang, H.; Kong, Z.; Xi, J.; Ji, Z. MnS coupled with ultrathin $\mathrm{MoS}_{2}$ nanolayers as heterojunction photocatalyst for high photocatalytic and photoelectrochemical activities. J. Alloys Compd. 2019, 771, 364-372. [CrossRef]

154. Dolai, S.; Dey, R.; Hussain, S.; Bhar, R.; Kumar Pal, A. Photovoltaic properties of F:SnO $\mathrm{S}_{2} / \mathrm{CdS} / \mathrm{CuO} / \mathrm{Ag}$ heterojunction solar cell. Mater. Res. Bull. 2019, 109, 1-9. [CrossRef]

155. Rosas-Laverde, N.M.; Pruna, A.; Busquets-Mataix, D.; Marí, B.; Cembrero, J.; Salas Vicente, F.; Orozco-Messana, J. Improving the properties of $\mathrm{Cu}_{2} \mathrm{O} / \mathrm{ZnO}$ heterojunction for photovoltaic application by graphene oxide. Ceram. Int. 2018, 44, 23045-23051. [CrossRef]

156. Liu, C.; Zhou, J.; Su, J.; Guo, L. Turning the unwanted surface bismuth enrichment to favourable $\mathrm{BiVO}_{4} / \mathrm{BiOCl}$ heterojunction for enhanced photoelectrochemical performance. Appl. Catal. B Environ. 2019, 241, 506-513. [CrossRef]

157. Mao, L.; Ji, K.; Yao, L.; Xue, X.; Wen, W.; Zhang, X.; Wang, S. Molecularly imprinted photoelectrochemical sensor for fumonisin B1 based on GO-CdS heterojunction. Biosens. Bioelectron. 2019, 127, 57-63. [CrossRef]

158. Zhou, W.; Jiang, T.; Zhao, Y.; Xu, C.; Pei, C.; Xue, H. Ultrathin Ti/TiO2/BiVO4 nanosheet heterojunction arrays for photoelectrochemical water oxidation. J. Alloys Compd. 2019, 777, 1152-1158. [CrossRef]

159. Martínez-Saucedo, G.; Castanedo-Pérez, R.; Torres-Delgado, G.; Márquez-Marín, J.; Zelaya-Ángel, O. Cuprous oxide/cadmium stannate heterojunction diodes obtained by dip-coating method. J. Alloys Compd. 2019, 774, 153-159. [CrossRef]

160. Sharma, A.; Tomar, M.; Gupta, V. Low temperature operating $\mathrm{SnO}_{2}$ thin film sensor loaded with $\mathrm{WO}_{3}$ micro-discs with enhanced response for $\mathrm{NO}_{2}$ gas. Sens. Actuators B Chem. 2012, 161, 1114-1118. [CrossRef]

161. Alali, K.T.; Lu, Z.; Zhang, H.; Liu, J.; Liu, Q.; Li, R.; Aljebawi, K.; Wang, J. P-p heterojunction CuO/CuCo $2 \mathrm{O}_{4}$ nanotubes synthesized via electrospinning technology for detecting n-propanol gas at room temperature. Inorg. Chem. Front. 2017, 4, 1219-1230. [CrossRef]

162. Tai, H.; Xu, X.; Ye, Z.; Liu, C.; Xie, G.; Jiang, Y. P-P heterojunction sensor of self-assembled polyaniline nano-thin film/microstructure silicon array for NH3 detection. Chem. Phys. Lett. 2015, 621, 58-64. [CrossRef]

163. Gong, J.; Li, Y.; Hu, Z.; Zhou, Z.; Deng, Y. Ultrasensitive $\mathrm{NH}_{3}$ Gas Sensor from Polyaniline Nanograin Enchased $\mathrm{TiO}_{2}$ Fibers. J. Phys. Chem. C 2010, 114, 9970-9974. [CrossRef]

164. Huang, H.; Gong, H.; Chow, C.L.; Guo, J.; White, T.J.; Tse, M.S.; Tan, O.K. Low-Temperature Growth of $\mathrm{SnO}_{2}$ Nanorod Arrays and Tunable n-p-n Sensing Response of a $\mathrm{ZnO} / \mathrm{SnO}_{2}$ Heterojunction for Exclusive Hydrogen Sensors. Adv. Funct. Mater. 2011, 21, 2680-2686. [CrossRef] 